Prepared in cooperation with the Cleveland County Sanitary District, North Carolina

\title{
Suspended Sediment and Bedload in the First Broad River Basin in Cleveland County, North Carolina, 2008-2009
}

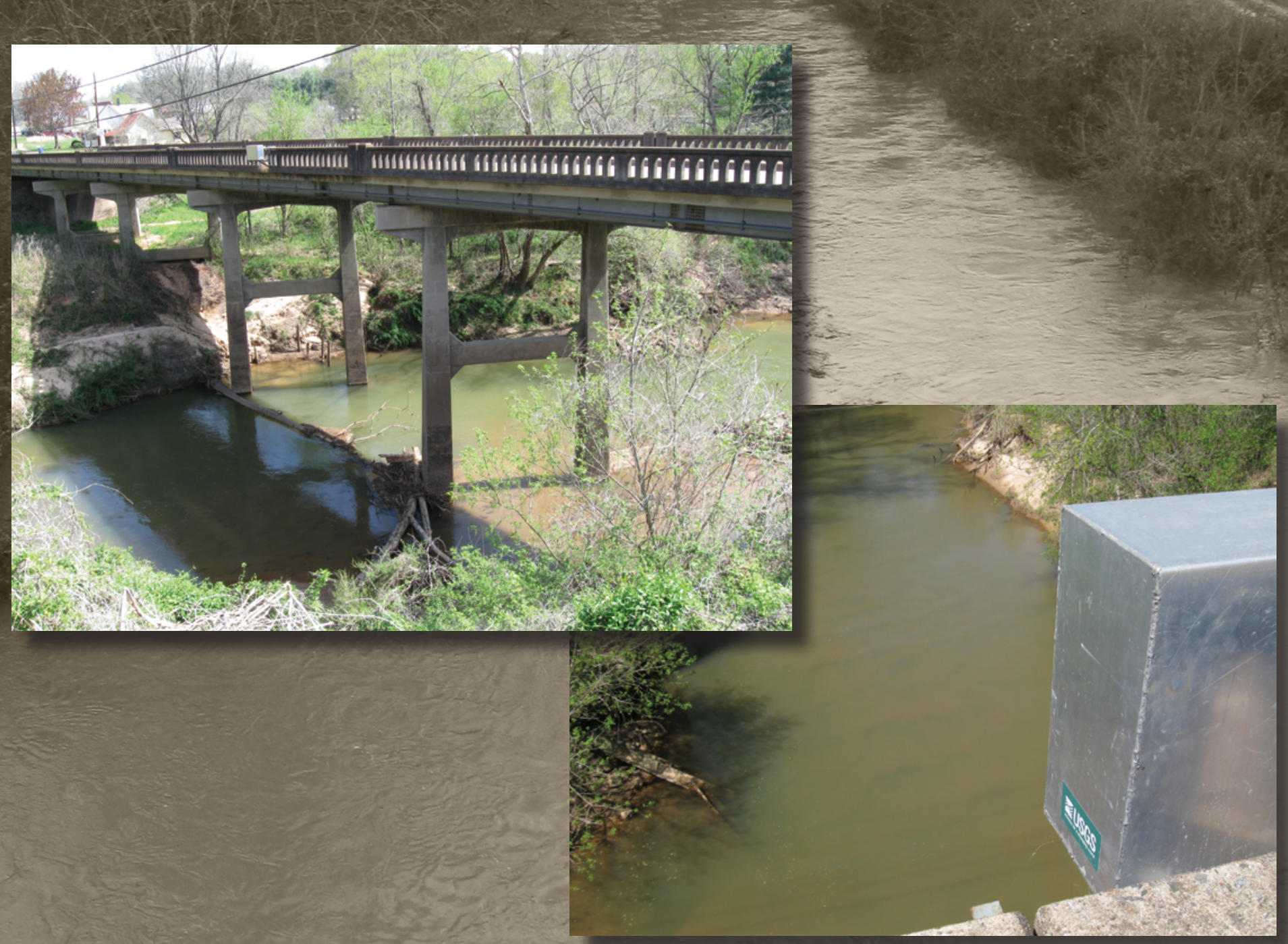

Scientific Investigations Report 2011-5079

U.S. Department of the Interior U.S. Geological Survey 
Cover photographs: Background photo—First Broad River, North Carolina, at FBR 2, looking upstream from bridge during high flow. Upper left photo-First Broad River, North Carolina, at FBR 3, looking at sediment sampler from upstream. Lower right photo-First Broad River, North Carolina, at FBR 3, looking upstream at sediment sampler. 


\section{Suspended Sediment and Bedload in the First Broad River Basin in Cleveland County, North Carolina, 2008-2009}

By William F. Hazell and Brad A. Huffman

Prepared in cooperation with the

Cleveland County Sanitary District, North Carolina

Scientific Investigations Report 2011-5079 


\title{
U.S. Department of the Interior \\ KEN SALAZAR, Secretary \\ U.S. Geological Survey \\ Marcia K. McNutt, Director
}

\author{
U.S. Geological Survey, Reston, Virginia: 2011
}

For more information on the USGS - the Federal source for science about the Earth, its natural and living resources, natural hazards, and the environment, visit http://www.usgs.gov or call 1-888-ASK-USGS.

For an overview of USGS information products, including maps, imagery, and publications, visit http://www.usgs.gov/pubprod

To order this and other USGS information products, visit http://store.usgs.gov

Any use of trade, product, or firm names is for descriptive purposes only and does not imply endorsement by the U.S. Government.

Although this report is in the public domain, permission must be secured from the individual copyright owners to reproduce any copyrighted materials contained within this report.

Suggested citation:

Hazell, W.F., and Huffman, B.A., 2011, Suspended sediment and bedload in the First Broad River Basin in Cleveland County, North Carolina, 2008-2009: U.S. Geological Survey Scientific Investigations Report 2011-5079, 20 p. 


\section{Acknowledgments}

Chris Hayes with Cleveland County Sanitary District deserves special recognition for his efforts in collecting suspended-sediment samples twice a week as well as during high-flow events at the two sites on the First Broad River during the investigation. 


\section{Contents}

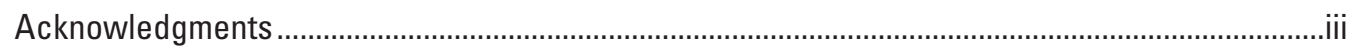

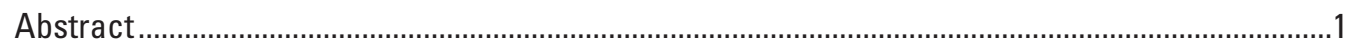

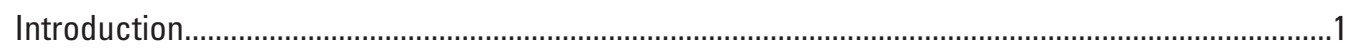

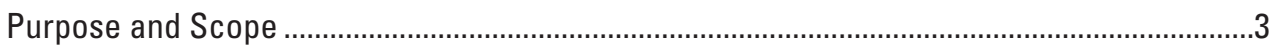

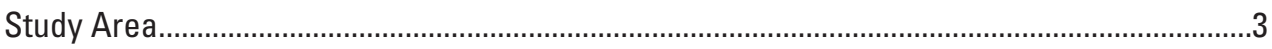

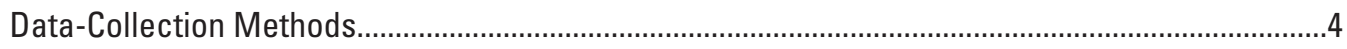

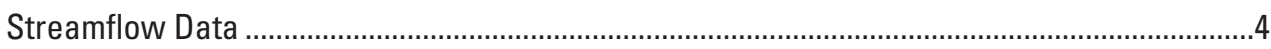

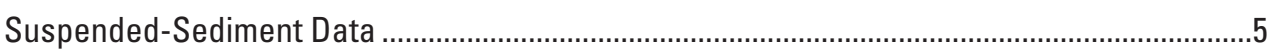

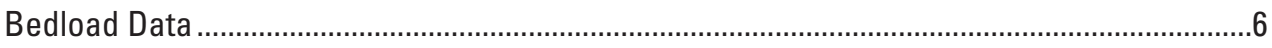

Analysis of Observed and Historical Data ...............................................................................

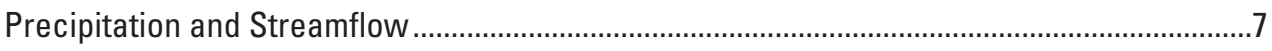

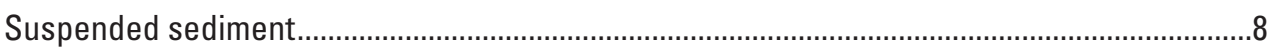

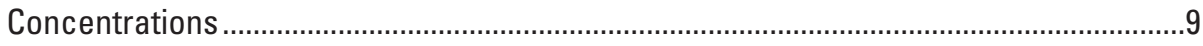

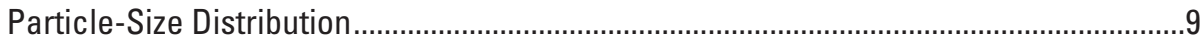

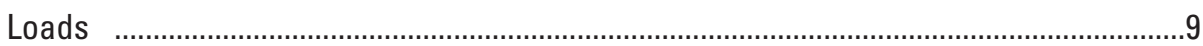

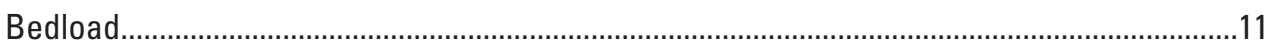

Particle-Size Distribution.........................................................................................13

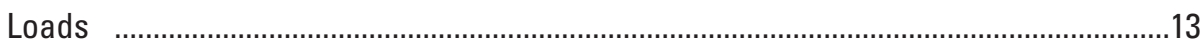

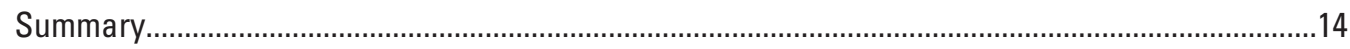

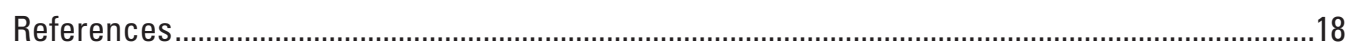

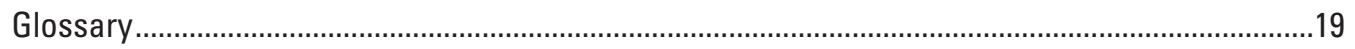

\section{Figures}

1. Map showing location of the First Broad River Basin in Cleveland County,

North Carolina ..................................................................................................................

2. Map showing locations of continuous streamflow and sediment-sampling sites in the First Broad River Basin, Cleveland County, North Carolina.......................................

3. Graph showing suspended-sediment samples with corresponding replicate samples collected between April 2008 and September 2009 at FBR2,

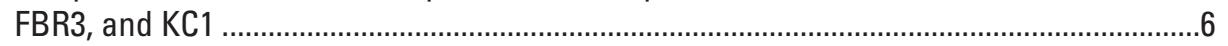

4. Photographs of US-D-74, US-DH-59, US-DH-48 suspended-sediment samplers, and US-BL-84 bedload sampler

5. Graph showing departure from normal monthly precipitation at the Casar climate station (Casar 311538), 2005-2009, Cleveland County, North Carolina...............................8

6. Graphs showing daily mean streamflow for April 2008-September 2009 and long-term daily mean streamflow, 1959-2008, at First Broad River near Casar (site FBR1) and daily mean streamflow for April 2008-September 2009 at First Broad River at Secondary Road 1512 near Lawndale (site FBR2) and First Broad River at Lawndale (site FBR3), Cleveland County, North Carolina.

7. Graph showing flow duration curves for sites FBR1, FBR2, and FBR3, and corresponding sample streamflow at sites FBR2 and FBR3, Cleveland County, North Carolina 
8. Graph showing range of streamflow measured during the study period and the discharge associated with suspended-sediment samples collected between March 2008 and September 2009 at sites FBR2 and FBR3, Cleveland County, North Carolina

9. Box plots showing the distribution of suspended-sediment concentrations from samples collected between March 2008 and September 2009 at FBR2, FBR3, and KC1, Cleveland County, North Carolina

10. Box plots showing the distribution of percentages of suspended-sediment particles finer than 0.0625 millimeters from samples collected between March 2008 and September 2009 at FBR2, FBR3, and KC1, Cleveland County, North Carolina

11. Graphs showing the relation between instantaneous suspended-sediment concentration and streamflow at sites FBR2 and FBR3, Cleveland County, North Carolina .....

12. Graphs showing the relation between estimated and measured suspended sediment loads at sites FBR2 and FBR3, Cleveland County, North Carolina

13. Graph showing estimated monthly suspended-sediment load and mean daily streamflow from April 2008 to September 2009 at FBR2 and FBR3, Cleveland County, North Carolina

\section{Tables}

1. Streamflow, suspended-sediment, and bedload monitoring sites in the Cleveland County study area, North Carolina, and annual mean streamflow and annual suspended-sediment load and yield data.

2. Percentage of time discharge at study sites in Cleveland County, North Carolina, equaled or exceeded specified discharge in a given period.

3. Total daily suspended-sediment loads at study sites in Cleveland County, North Carolina, for seven high-flow events during the 2009 water year.

4. Bedload samples collected at sites FBR1, FBR2, and KC1, in Cleveland County, North Carolina, March 2008-September 2009

5. Instantaneous suspended-sediment load, bedload, and total load for samples collected at sites FBR2, FBR3, and KC1, Cleveland County, North Carolina, March 2008-September 2009 


\section{Conversion Factors}

\begin{tabular}{|c|c|c|}
\hline Multiply & By & To obtain \\
\hline \multicolumn{3}{|c|}{ Length } \\
\hline inch (in) & 2.54 & centimeter $(\mathrm{cm})$ \\
\hline inch (in) & 25.4 & millimeter $(\mathrm{mm})$ \\
\hline foot $(\mathrm{ft})$ & 0.3048 & meter $(\mathrm{m})$ \\
\hline mile (mi) & 1.609 & kilometer $(\mathrm{km})$ \\
\hline \multicolumn{3}{|c|}{ Area } \\
\hline acre & 0.4047 & hectare (ha) \\
\hline square mile $\left(\mathrm{mi}^{2}\right)$ & 2.590 & square kilometer $\left(\mathrm{km}^{2}\right)$ \\
\hline \multicolumn{3}{|c|}{ Volume } \\
\hline gallon (gal) & 3.785 & liter $(\mathrm{L})$ \\
\hline cubic foot $\left(\mathrm{ft}^{3}\right)$ & 0.02832 & cubic meter $\left(\mathrm{m}^{3}\right)$ \\
\hline \multicolumn{3}{|c|}{ Flow rate } \\
\hline foot per second (ft/s) & 0.3048 & meter per second $(\mathrm{m} / \mathrm{s})$ \\
\hline cubic foot per second $\left(\mathrm{ft}^{3} / \mathrm{s}\right)$ & 0.02832 & cubic meter per second $\left(\mathrm{m}^{3} / \mathrm{s}\right)$ \\
\hline $\begin{array}{l}\text { cubic foot per second per square } \\
\text { mile }\left[\left(\mathrm{ft}^{3} / \mathrm{s}\right) / \mathrm{mi}^{2}\right]\end{array}$ & 0.01093 & $\begin{array}{l}\text { cubic meter per second per square } \\
\text { kilometer }\left[\left(\mathrm{m}^{3} / \mathrm{s}\right) / \mathrm{km}^{2}\right]\end{array}$ \\
\hline million gallons per day (Mgal/d) & 0.04381 & cubic meter per second $\left(\mathrm{m}^{3} / \mathrm{s}\right)$ \\
\hline \multicolumn{3}{|c|}{ Mass } \\
\hline pound (lb) & 453.59 & gram $(g)$ \\
\hline ton, short $(2,000 \mathrm{lb})$ & 0.9072 & megagram $(\mathrm{Mg})$ or metric ton $(\mathrm{Mt})$ \\
\hline ton per day (ton/d) & 0.9072 & metric ton per day $(\mathrm{Mt} / \mathrm{d})$ \\
\hline ton per year (ton/yr) & 0.9072 & metric ton per year $(\mathrm{Mt} / \mathrm{yr})$ \\
\hline inch per year per foot $[(\mathrm{in} / \mathrm{yr}) / \mathrm{ft}]$ & 83.33 & $\begin{array}{l}\text { millimeter per year per meter } \\
\qquad[(\mathrm{mm} / \mathrm{yr}) / \mathrm{m}]\end{array}$ \\
\hline
\end{tabular}

Vertical coordinate information is referenced to the National Geodetic Vertical Datum of 1929 (NGVD 29).

Altitude, as used in this report, refers to distance above the vertical datum.

Concentrations of chemical constituents in water are given in milligrams per liter (mg/L). 



\title{
Suspended Sediment and Bedload in the First Broad River Basin in Cleveland County, North Carolina, 2008-2009
}

\author{
By William F. Hazell and Brad A. Huffman
}

\section{Abstract}

A study was conducted to characterize sediment transport upstream and downstream from a proposed dam on the First Broad River near the town of Lawndale in Cleveland County, North Carolina. Streamflow was measured continuously, and 381 suspended-sediment samples were collected between late March 2008 and September 2009 at two monitoring stations on the First Broad River to determine the suspended-sediment load at each site for the period April 2008-September 2009. In addition, 22 bedload samples were collected at the two sites to describe the relative contribution of bedload to total sediment load during selected events. Instantaneous streamflow, suspended-sediment, and bedload samples were collected at Knob Creek near Lawndale, North Carolina, to describe general suspended-sediment and bedload characteristics at this tributary to the First Broad River. Suspended- and bedloadsediment samples were collected at all three sites during a variety of flow conditions. Streamflow and suspendedsediment measurements were compared with historical data from a long-term (1959-2009) streamflow station located upstream from Lawndale. The mean streamflow at the long-term streamflow station was approximately 60 percent less during the study period than the long-term annual mean streamflow for the site.

Suspended-sediment concentrations and continuous records of streamflow were used to estimate suspendedsediment loads and yields at the two monitoring stations on the First Broad River for the period April 2008-September 2009 and for a complete annual cycle (October 2008-September 2009), also known as a water year. Total suspended-sediment loads during water year 2009 were 18,700 and 36,500 tons at the two sites. High-flow events accounted for a large percentage of the total load, suggesting that the bulk of the total suspended-sediment load was transported during these events. Suspended-sediment yields during water year 2009 were 145 and 192 tons per square mile at the two monitoring stations. Historically, the estimated mean annual suspended-sediment yield at the long-term streamflow station during the period 1970-1979 was 250 tons per square mile, with an estimated mean annual suspended-sediment load of 15,000 tons. Drought conditions throughout most of the study period were a potential factor in the smaller yields at the monitoring stations compared to the yields estimated at the long-term streamflow station in the 1970s.

During an extreme runoff event on January 7, 2009, bedload was 0.4 percent, 0.8 percent, and 0.1 percent of the total load at the three study sites, which indicates that during extreme runoff conditions the percentage of the total load that is bedload is not significant. The percentages of the total load that is bedload during low-flow conditions ranged from 0.1 to 90.8 , which indicate that the bedload is variable both spatially and temporally.

\section{Introduction}

Cleveland County is located in the southwestern part of the Piedmont Physiographic Province of North Carolina (fig. 1). Repeated cycles of drought, most notably 1998-2002, and more recently 2007-2009, have raised concerns for the need of an additional source of drinking water in Cleveland County. Flows at site FBR1 during these periods were as low as 3.9 cubic feet per second $\left(\mathrm{ft}^{3} / \mathrm{s}\right)$ in 2002 (period of record low) and $6.4 \mathrm{ft}^{3} / \mathrm{s}$ in 2008. The Cleveland County Sanitary District (CCSD), which supplies water to more than 55,000 customers, obtains water from the First Broad River and Knob Creek just upstream from the town of Lawndale. Total withdrawals during the study period were 2,102 million gallons, resulting in an average of 3.8 million gallons per day (Mgal/d) (Butch Smith, Cleveland County Sanitary District, written commun., January 2011). Water-supply demands in the CCSD service area are expected to increase by more than 50 percent by 2050 . Population growth, along with potential future droughts, could severely stress capacity of the current water-supply system. To prepare for anticipated increase in demand, the CCSD is proposing to construct a dam and watersupply reservoir on the First Broad River, north of the town of Lawndale (Butch Smith, Cleveland County Sanitary District, oral commun., January 2008). 


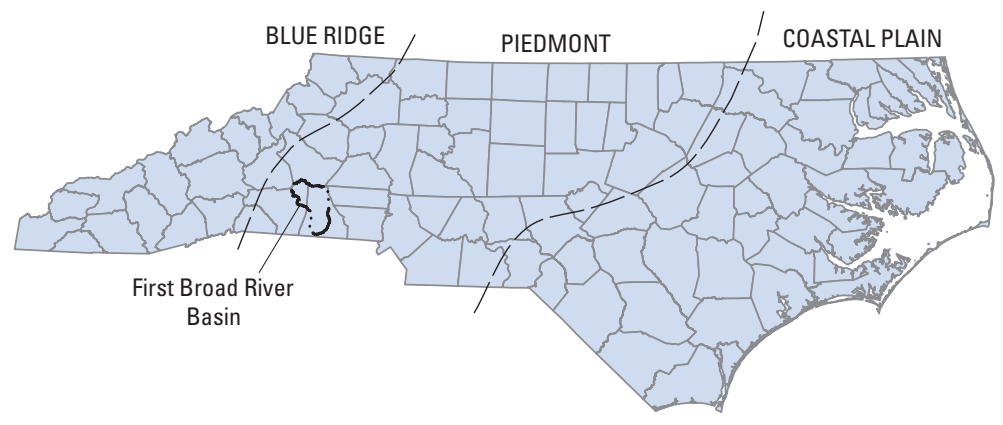

Location of First Broad River Basin and Piedmont Physiographic Province in North Carolina

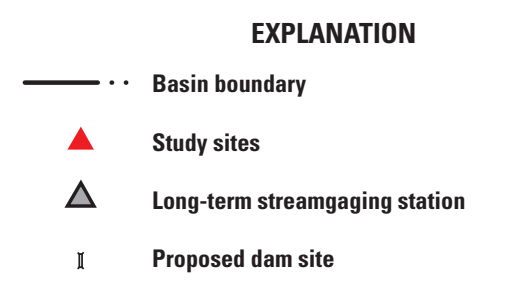

Note: Boxed area is enlarged in figure 2.

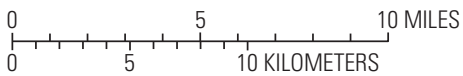

$81^{\circ} 30^{\prime}$

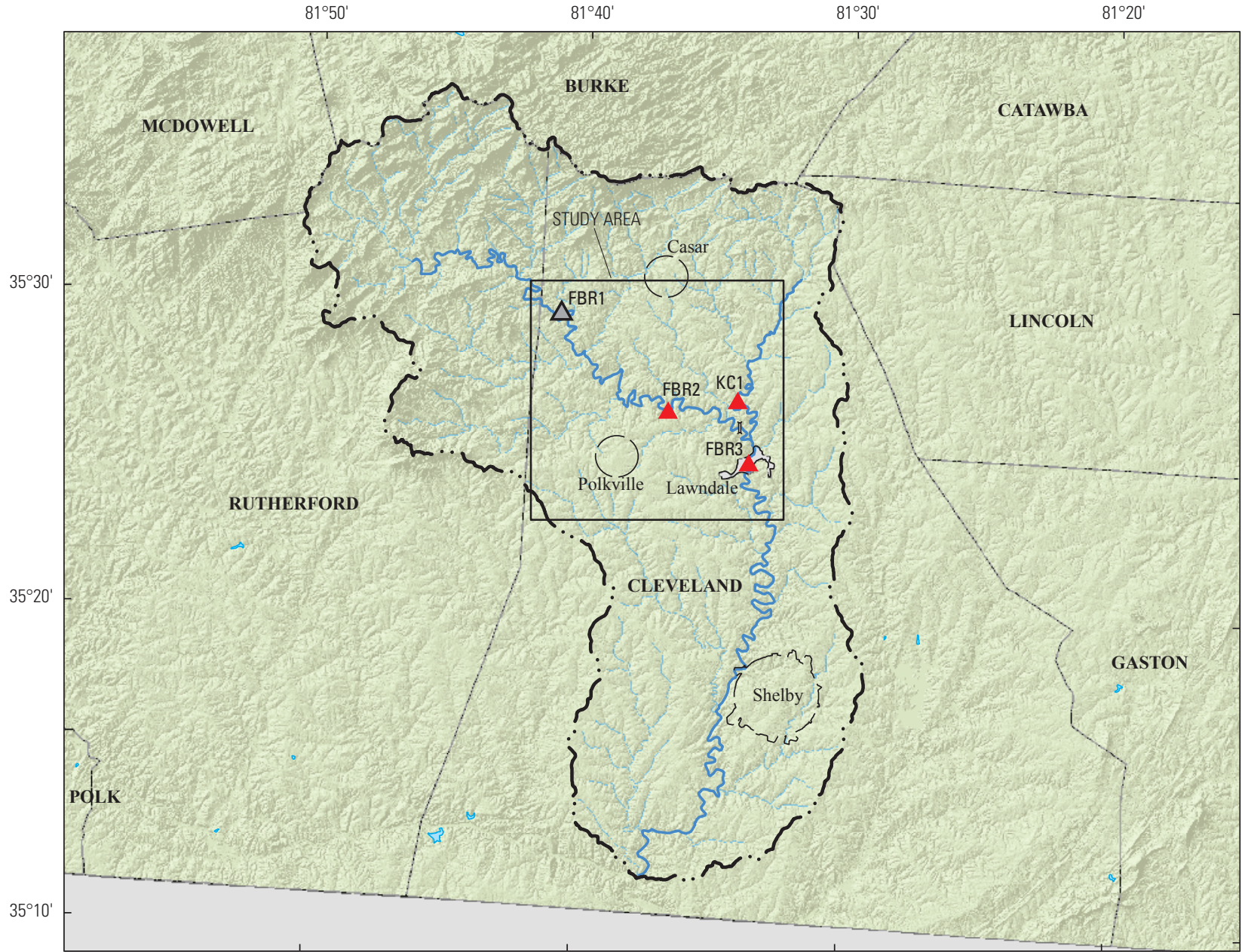

Base modified from NC Floodplain Mapping Program, North Carolina Division of Emergency Management: French Broad River Basin; $20 \mathrm{ft}$ Digital Elevation Model, Light Detection and Ranging Imagery, 2004. Albers NAD 1983

Figure 1. Location of the First Broad River Basin in Cleveland County, North Carolina.

Dams interrupt the flow of water and, therefore, sediment, resulting in sediment deposition in a reservoir. Reservoirs typically alter the downstream hydraulic relation and reduce the sediment supply, which can lead to the degradation (bank erosion, channel downcutting, and so forth) of the downstream channel. Sedimentation investigations typically involve the evaluation of the existing condition as well as the modified condition.
The proposed reservoir is sized to meet the projected needs of the water users; however, rates of reservoir sedimentation cannot be estimated, because current data are lacking for sediment transport in the First Broad River. Understanding sedimentation rates is critical to water-supply planning, because sediment accumulation decreases the amount of available storage and determines the usable life of the reservoir. 
Reservoir projects typically require a sediment load analysis to determine the potential storage depletion resulting from the deposition of sediment during the estimated life of the project. Because total sediment load consists of both suspended sediment and bedload, data collection should account for both of these transport modes. Depending on water velocity and the retention time of a reservoir, the finest material may not be deposited. Thus, grain size analysis of fluvial sediment provides information useful for estimating sediment deposition in a reservoir.

A comprehensive study was conducted in the 1970 s to characterize suspended-sediment characteristics in streams across North Carolina (Simmons, 1993). More than 13,000 samples were collected to determine, among other characteristics, mean annual suspended-sediment load and yield at 152 stream sites. One of the sites, 02152100, First Broad River near Casar, NC (referred to as FBR1 in this report), was located upstream from the proposed dam location in Cleveland County and provides a historical benchmark for the current study. Average annual sediment yield at this site was 250 tons per square mile (tons $/ \mathrm{mi}^{2}$ ). Samples collected in the Piedmont Physiographic Province contained some of the State's highest concentrations of suspended sediment (Simmons, 1993), which is attributed to the combination of intense rains, relatively steep gradients, and the highly erodible clayey soils. No additional statewide investigations of sediment transport have been done.

The previous study (Simmons, 1993) provided a historical benchmark (FBR1) for this current study prepared by the U.S. Geological Survey (USGS) in cooperation with CCSD. Results from this study provide a better understanding of sediment transport in the First Broad River by quantifying the suspended (concentration and particle size) and bedload characteristics, and in turn sedimentation rates, which is critical in the planning of a water supply reservoir. This study also provides a valuable benchmark for comparison with future, modified conditions. Continued periodic sampling and analysis of sediment transport would be beneficial for monitoring the sustainability of CCSD's water supply.

\section{Purpose and Scope}

The purpose of the report is to present estimates of sediment load at two study sites on the First Broad River for the period April 2008 through September 2009. Continuous streamflow was measured from April 2008 to September 2009, and 381 suspended-sediment samples were collected between late March 2008 and September 2009 at the First Broad River at SR1512 near Lawndale, NC (FBR2) and the First Broad River at Lawndale, NC (FBR3) in order to define relations between suspended-sediment concentration and streamflow. Site FBR2 and site FBR3 are located on the mainstem of the First Broad River, upstream and downstream from a proposed dam in Cleveland County, North Carolina. Suspendedsediment load was computed at each site for the period
April 2008 through September 2009. In addition, 22 bedload samples were collected at these two sites to describe the relative contribution of bedload to total sediment load during selected events.

In addition, suspended-sediment and bedload characteristics are described for Knob Creek near Lawndale, $\mathrm{NC}(\mathrm{KC} 1)$, the largest tributary to the First Broad River upstream from Lawndale. Instantaneous streamflow, along with 7 suspended-sediment and 7 bedload samples, were collected from March 2008 to August 2009. Continuous streamflow was not recorded at $\mathrm{KC} 1$; therefore, loads were not computed for this tributary.

At all three sites, suspended and bedload sediment samples were collected across a range of flow conditions. Streamflow and suspended-sediment results were compared with historical data from the long-term (1959-2009) streamflow station (FBR1).

\section{Study Area}

The First Broad River Basin is located in southwestern North Carolina, in the Piedmont Physiographic Province (fig. 1). The Piedmont Physiographic Province occupies about 45 percent of the State's area (Simmons, 1993). The First Broad River begins in northern Rutherford County and drains into the Broad River in southern Cleveland County. The study area is in the north-central part of Cleveland County near the town of Lawndale. The topography of the study area is characterized by steep, prominent hills and low-lying mountains in the headwater area, transitioning to more well-rounded hills and long, rolling ridges (Simmons, 1993). The soil characteristics of the study area generally consist of a well-drained sandy, clay loam with clayey subsoil (National Resource Conservation Service, 2006). Land use upstream from site FBR3 is approximately 81 percent forested, 18 percent pasture/row crops, and 1 percent other. The average annual precipitation of the study area is estimated to be 50 inches at a nearby meteorological station (Casar 311538; State Climate Office of North Carolina, CRONOS database), which is fairly evenly distributed throughout the year.

Altitudes in the Piedmont Physiographic Province range from more than 1,500 feet (ft) above NGVD of 1929 along the western boundary to 300 to $600 \mathrm{ft}$ along the eastern boundary. Altitudes at sampling sites ranged from $800 \mathrm{ft}$ (at FBR3) to $845 \mathrm{ft}$ (at FBR2) above NGVD of 1929. Stream gradients in the study area are sufficient to produce stream velocities of 5 to 10 feet per second ( $\mathrm{ft} / \mathrm{s}$ ) during high flows (Simmons, 1993). The maximum velocity measured during discharge measurements made at the three study sites was $10.2 \mathrm{ft} / \mathrm{s}$, and the maximum mean velocity for discharge measurements was $3.95 \mathrm{ft} / \mathrm{s}$. 


\section{Data-Collection Methods}

Between March 2008 and September 2009, continuous streamflow, suspended-sediment, and bedload sediment data were collected at two monitoring sites on the mainstem of the First Broad River, the First Broad River at Secondary Road 1512 near Lawndale (FBR2), and the First Broad River at Lawndale (FBR3), (fig. 2; table 1) to evaluate sediment transport at the two sites. A limited amount of instantaneous streamflow, suspended-sediment, and bedload sediment data also were collected at Knob Creek near Lawndale (KC1; fig. 2; table 1) to document suspended-sediment and bedload characteristics for this tributary to the First Broad River. Estimating sediment load at Knob Creek was not an objective of this study. Also, the First Broad River near Casar (FBR1), which is a long-term streamflow station (1959-present) located in the First Broad River Basin, was used as a comparison station for streamflow and suspended sediment at the study sites.

Site FBR2 was located upstream from the proposed dam location, and site FBR3 was located downstream. The drainage areas of these sites are 129 square miles $\left(\mathrm{mi}^{2}\right)$ and $190 \mathrm{mi}^{2}$, respectively, and the drainage area at the proposed dam location is approximately $155 \mathrm{mi}^{2}$. Site $\mathrm{KC1}$, has a drainage area of $33.3 \mathrm{mi}^{2}$ and is located approximately 3 miles (mi) upstream from Knob Creek's confluence with the First Broad River, approximately $1 \mathrm{mi}$ upstream from site FBR3 and 5.6 mi. downstream from site FBR2 (fig. 2).

Streamflow, suspended-sediment, and bedload measurements were made and quality assurance procedures were followed in accordance with established USGS protocols. Results of all sediment analyses, as well as stage and discharge data, are stored in the USGS National Water Information System (NWIS) database and published in USGS annual water data reports (U.S. Geological Survey, 2009-2011).

\section{Streamflow Data}

First Broad River near Casar (FBR1) is a long-term streamflow station (1959-present) located in the First Broad River Basin (fig. 2; table 1). This streamgage is operated and maintained by the USGS in cooperation with the North Carolina Department of Environment and Natural Resources. Although this gage was not part of the current study, data from the site are useful for comparing streamflow at the two First Broad River sites downstream and providing a historical context for interpreting results of the current study.

USGS streamgaging stations were established at sites FBR2 and FBR3 to obtain continuous streamflow records

EXPLANATION
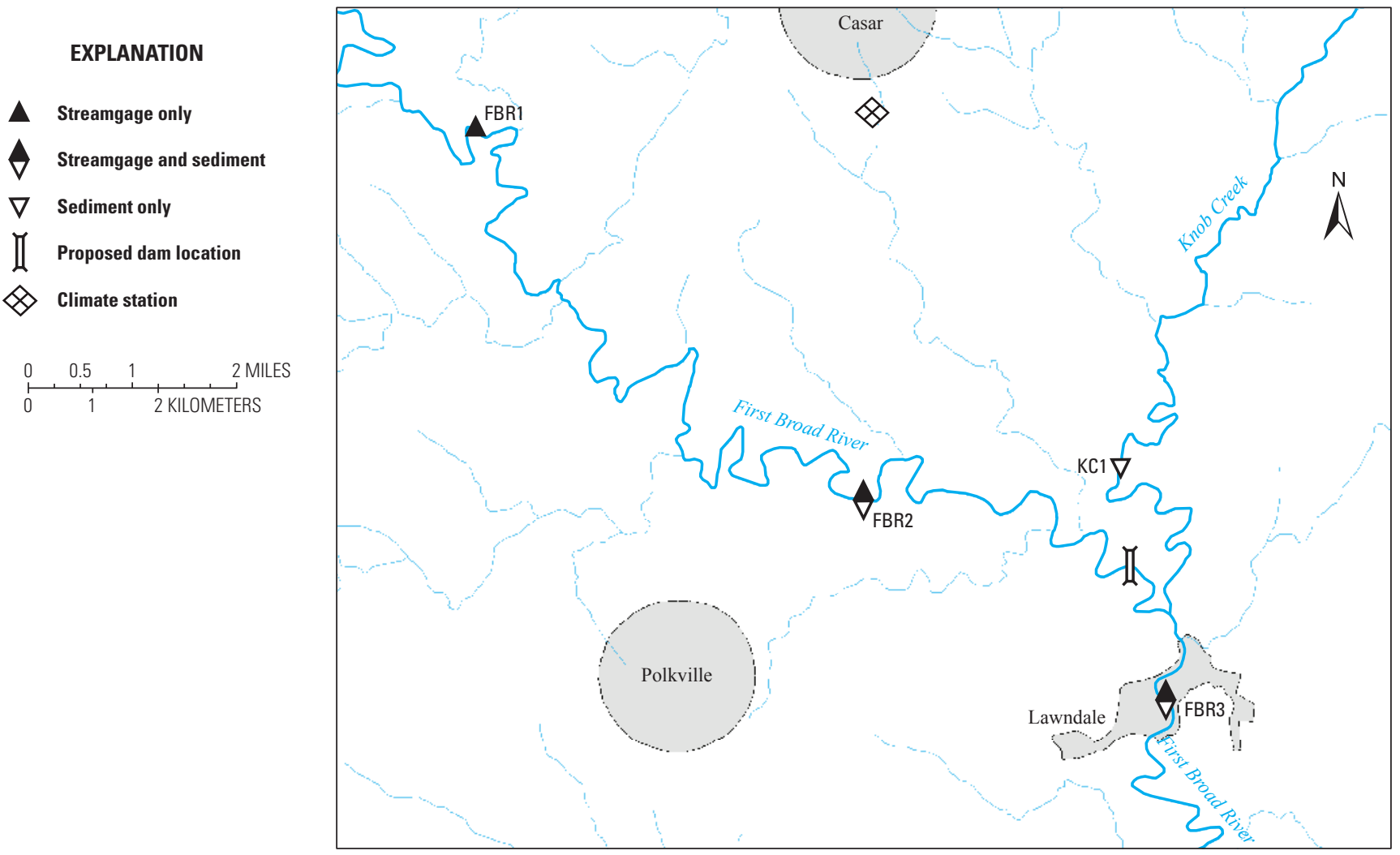

Base from: $100 \mathrm{k}$ city and stream coverage, GIS database

Figure 2. Locations of continuous streamflow and sediment-sampling sites in the First Broad River Basin, Cleveland County, North Carolina. 


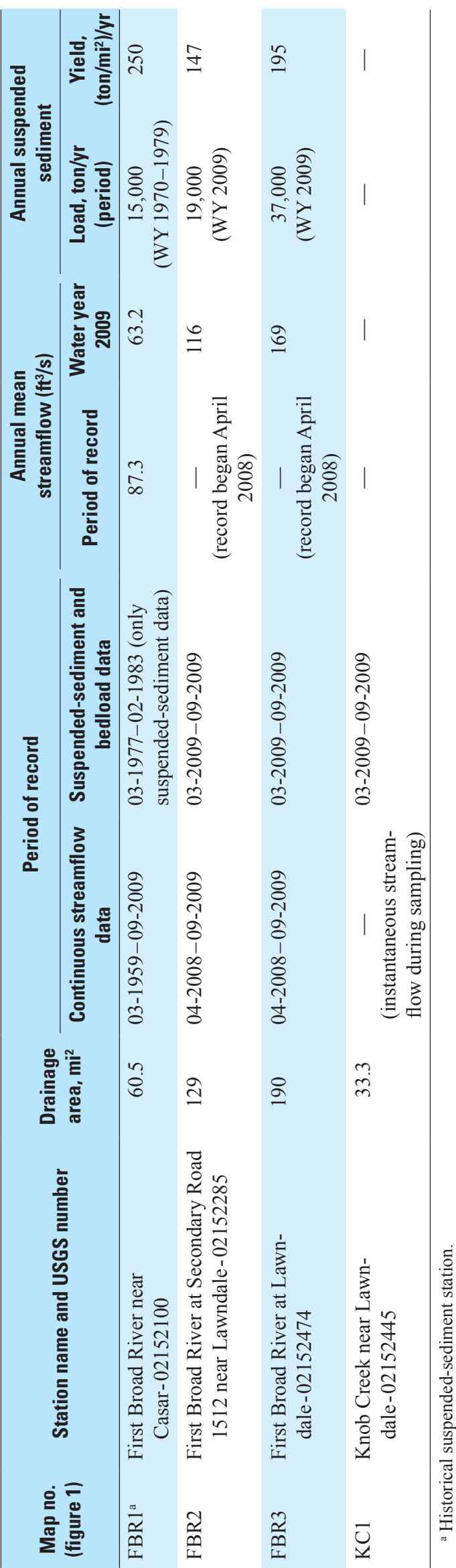

for the period April 2008 through September 2009 (fig. 2; table 1). Mean daily discharge prior to April 9 (at FBR2) and April 11 (at FBR3) was estimated from streamflow record at site FBR1. Streamflow was not recorded continuously at site $\mathrm{KC} 1$; however, instantaneous streamflow was measured at the time suspended-sediment and bedload samples were collected (fig. 2; table 1). All streamflow data were collected and quality assurance procedures were followed according to USGS protocols (Rantz and others, 1982; Simpson, 2001; Mueller and Wagner, 2009).

\section{Suspended-Sediment Data}

Suspended-sediment samples were collected twice a week and during high flows at sites FBR2 and FBR3 by personnel from the CCSD. Suspended-sediment samples and bedload samples were collected periodically by USGS personnel at sites FBR2, FBR3, and $\mathrm{KC} 1$ during a variety of flow conditions. During the period March 2008 through September 2009, 388 suspended-sediment samples and 29 bedload samples were collected at the study sites. Suspended-sediment sample results were used to define the relations between suspended-sediment concentration and streamflow at sites FBR2 and FBR3 and to describe general sediment characteristics at site KC1. Samples determined as outliers during analysis are not included in this report.

The sediment observer with the CCSD was trained by USGS personnel in proper sampling techniques and was provided with a copy of the "Instruction Manual for U.S. Geological Survey Sediment Observers" (Johnson, 1997) as a reference. Sampling techniques used by the observer were reviewed by USGS personnel approximately monthly. Replicate suspended-sediment samples were collected by the observer approximately monthly to quantify sampling reproducibility. A total of 49 replicate samples were collected throughout the study period at varying flow conditions (fig. 3).

A fixed sampling point was established at the approximate center of flow at sites FBR2 and FBR3 for the collection of the suspended-sediment samples. A box enclosure containing a cable-mounted US-D-74 suspendedsediment sampler (fig. $4 A$ ) was installed on the bridge rail at each site. Cleveland County Sanitary District staff used this equipment to collect single-vertical, depth-integrated suspended-sediment samples (fixed station sample) twice a week and during high flows. A US-DH-59 sampler (fig. 4B) on a hand line was used at the enclosure location when sampling during periods of low velocities and depths. The US-D-74 and US-DH-59 samplers were designed by the Federal Interagency Sedimentation Project (FISP) for collecting isokinetic suspended-sediment samples under various flow conditions (Davis, 2005). These samplers are used to collect depth-integrated samples from the water surface to within approximately 4 inches above the streambed. 

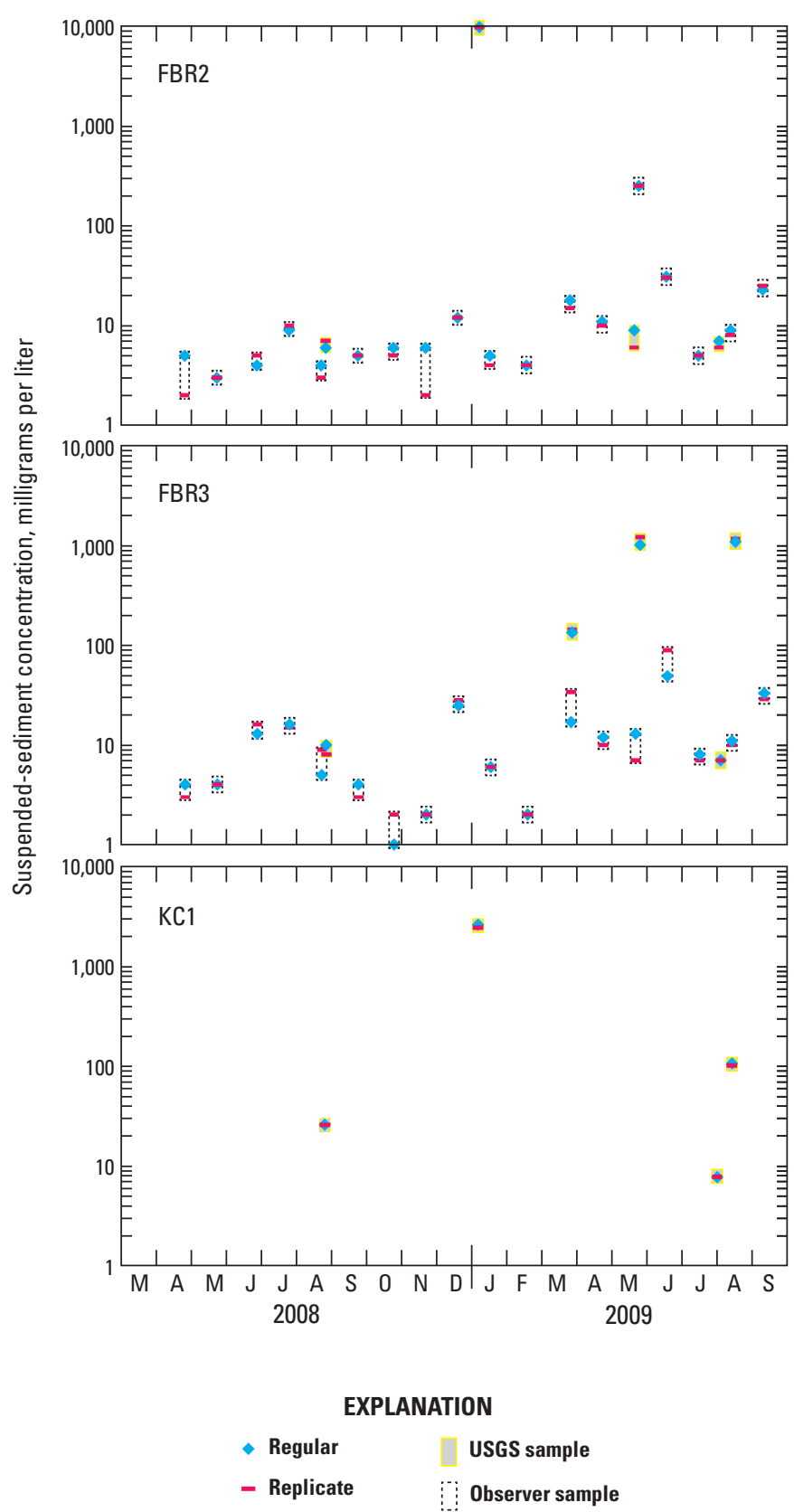

Figure 3. Suspended-sediment samples with corresponding replicate samples collected between April 2008 and September 2009 at FBR2, FBR3, and KC1.

U.S. Geological Survey personnel used a US DH-59 or US DH-48 (fig. 4B, $C$; Davis, 2005) sampler periodically to collect width- and depth-integrated suspended-sediment samples across the entire channel cross section at the three study sites. At site FBR2 and FBR3, these samples were used to verify that the single-vertical, depth-integrated samples collected at the fixed sampling point adequately represented the suspended-sediment concentrations in the stream cross section. Cross sections were sampled using the equal-widthincrement (EWI) method, following published USGS protocols (Edwards and Glysson, 1999).
Samples were shipped to the USGS sediment laboratory in Louisville, Kentucky, and analyzed for suspended-sediment concentration using methods described by Guy (1969). Selected samples were also analyzed to determine the percentage of particles that were finer than sand, that is, with diameters less than 0.0625 millimeter $(\mathrm{mm})$, by using a wet-sieving method (Shreve and Downs, 2005).

Suspended-sediment concentrations obtained using the EWI method were compared with concentrations from concurrent samples collected at the fixed sampling point, and theoretical correction coefficients were calculated. The coefficients averaged 1.06 for site FBR2 and 0.99 for site FBR3. Because suspended-sediment concentrations at the fixed sampling point generally were within 5 percent of the concentrations in the stream cross section, no corrections were applied.

\section{Bedload Data}

Bedload is the sediment that moves by sliding, rolling, or bouncing along on or very near the streambed. Bedload is difficult to measure accurately, because samplers placed on the streambed may disturb the flow and rate of bedload movement, and the bedload can vary both spatially and temporally. Despite these difficulties, 29 samples were collected to provide estimates of the bedload transport.

A US BL-84 sampler (fig. 4D) was used to sample bedload sediment. This cable-suspended bedload sampler is designed to collect particles ranging from $0.25 \mathrm{~mm}$ (the sample bag mesh opening) to $38 \mathrm{~mm}$ at stream velocities up to $9 \mathrm{ft} / \mathrm{s}$. The sampler has a 3-by 3 -inch entrance nozzle and an area expansion ratio (ratio of nozzle exit area to entrance area) of 1.4 (Edwards and Glysson, 1999). A polyester mesh sample bag with mesh openings of $0.25 \mathrm{~mm}$ was attached to the rear of the sampler. Samples were collected at each stream site by using a modified single equal-width-increment (SEWI) method (Edwards and Glysson, 1999). Each stream cross section was sampled by collecting subsamples at five evenly spaced locations. Bedload subsamples were combined into one composite sample for each transect. At least two transects were collected during sampling events, which typically were treated individually. During the sampling event on January 7 , 2009 , the two transects were composited and treated as one sample as a comparison of collection and processing techniques. The sampler was positioned on the streambed at each location for the same time interval during individual transects. The time interval varied among sampling events depending on the magnitude of streamflow. The average streamflow during the sampling period, stream width, number of subsections, length of time the sampler was on the streambed at each subsection, and total sampling time were recorded for each transect. Bedload samples were analyzed at the USGS sediment laboratory in Louisville, Kentucky, for total weight and particle-size distribution, ranging from diameters less than $0.0625 \mathrm{~mm}$ to less than $16 \mathrm{~mm}$ and using sieving methods 
$\boldsymbol{A}$

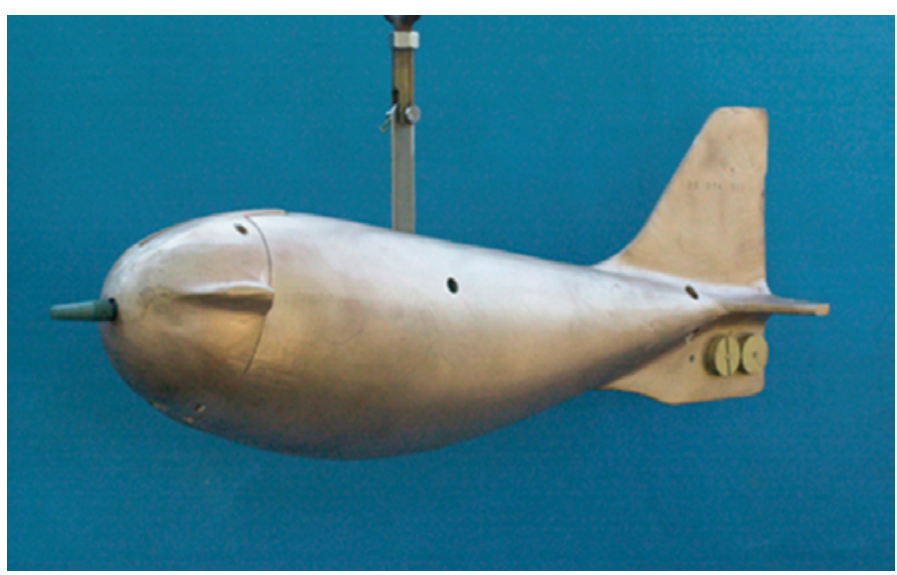

C

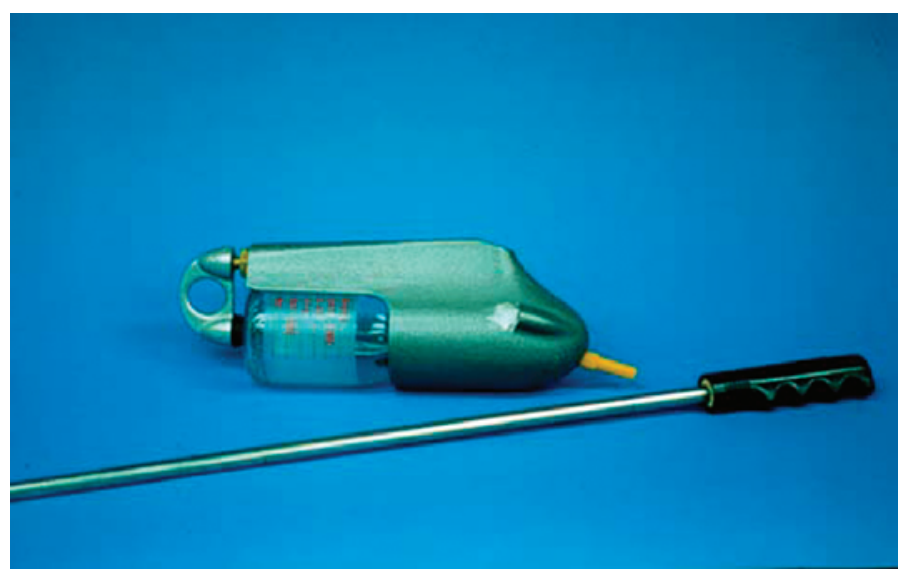

B

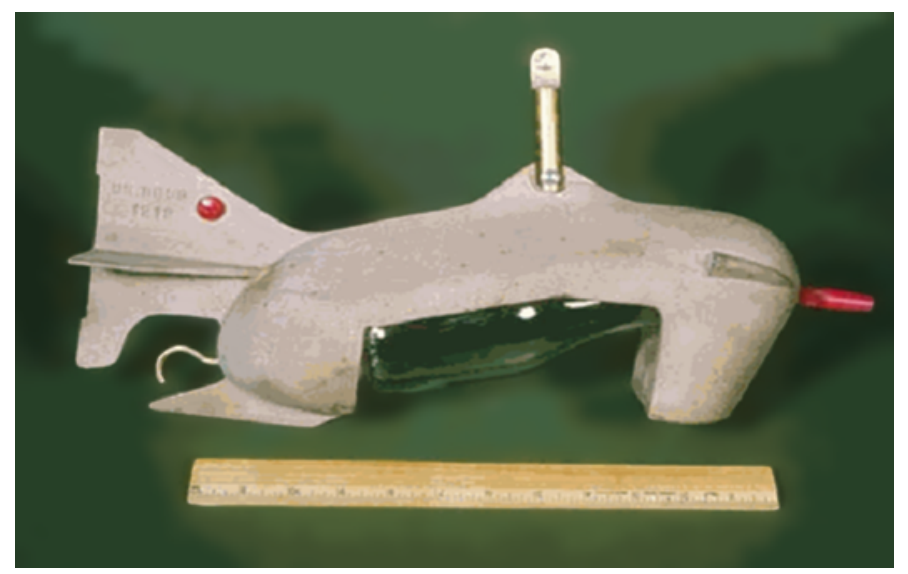

D

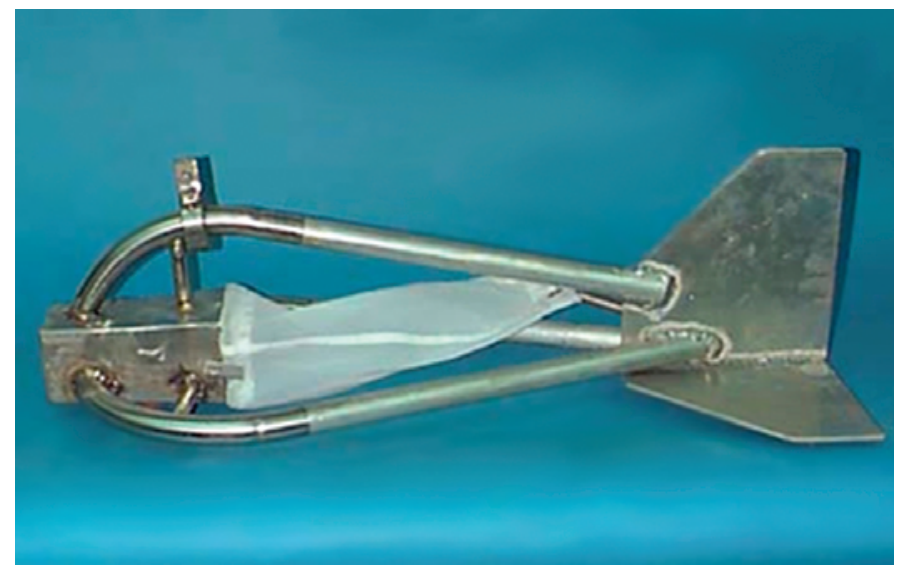

Figure 4. ( $A$ ) US-D-74, (B) US-DH-59, (C) US-DH-48 suspended-sediment samplers, and (D) US-BL-84 bedload sampler.

described by Guy (1969). As bedload sediment collected in the bag, the size of the mesh openings decreased, resulting in the collection of particle sizes less than the mesh size of the sample bag $(0.25 \mathrm{~mm})$. Quality assurance procedures used by the laboratory are documented in the "Quality-Assurance Plan for the Analysis of Fluvial Sediment by the U.S. Geological Survey Kentucky Water Science Center Sediment Laboratory" (Shreve and Downs, 2005).

\section{Analysis of Observed and Historical Data}

In addition to data collected for this study, historical streamflow and suspended-sediment data from FBR1 and precipitation data from a nearby meteorological site were compiled. These data are presented in the following sections of this report.

\section{Precipitation and Streamflow}

The State Climate Office of North Carolina maintains a meteorological data station (Casar 311538; State Climate Office of North Carolina, CRONOS database) about 6 miles northwest of Lawndale (fig. 2). Based on records for the period 1971 to 2000, the average annual precipitation at the Casar station is 50.1 inches per year (in/yr). Based on long-term monthly averages, the normal precipitation for the 18-month study period (April 2008-September 2009) is 75.4 inches. The total precipitation measured at the Casar station during the study period was 80.1 inches (6 percent above normal; fig. 5). Although the total precipitation for the entire study period was slightly above normal, the beginning of the study period was affected by considerable drought. Monthly departures from the long-term monthly averages were almost entirely negative at the Casar station during the 3 years prior to the study period (fig. 5). Based on the Palmer Modified Drought Index (National Oceanic and Atmospheric Administration, 2010), conditions ranged from moderate to severe drought in the vicinity of the study area beginning April 2007 and returned to normal in May 2009. 


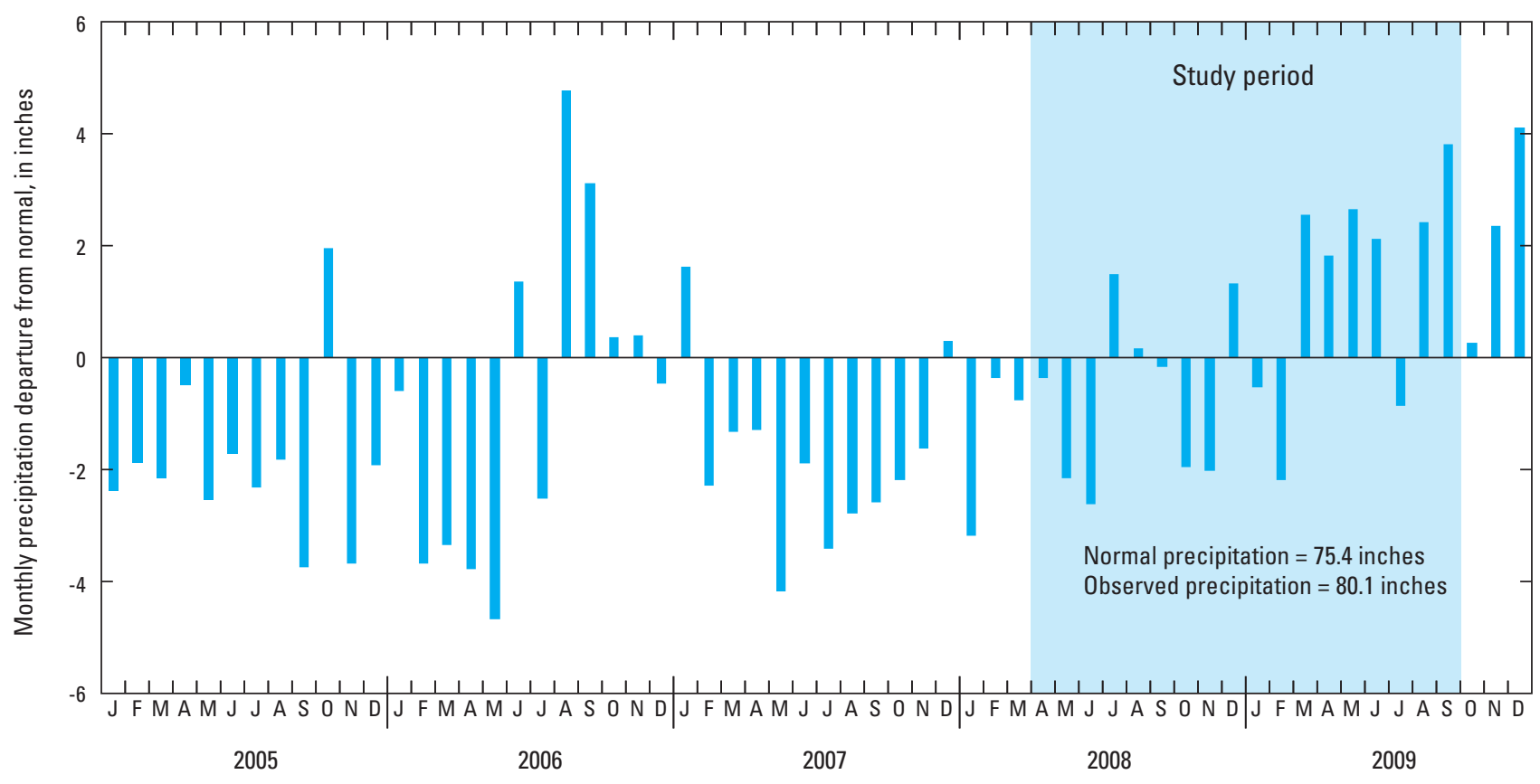

Figure 5. Departure from normal monthly precipitation at the Casar climate station (Casar 311538), 2005-2009, Cleveland County, North Carolina.

The long-term annual mean streamflow for the period 1959-2009 was $87.3 \mathrm{ft}^{3} / \mathrm{s}$ at site FBR1 (fig. 6A). The annual mean streamflow for the 2008 water year (October 1, 2007 through September 30, 2008) and the 2009 water year (October 1, 2008 through September 30, 2009) was $33.3 \mathrm{ft} 3 / \mathrm{s}$ and $63.2 \mathrm{ft}^{3} / \mathrm{s}$, respectively. Lingering drought conditions, which persisted into 2009 , resulted in below average flows throughout most of the study period. It was not until September 2009 that flow conditions were back to near normal. The mean streamflow at site FBR1 during the study period was $51.3 \mathrm{ft}^{3} / \mathrm{s}$, which is approximately 60 percent of the long-term annual mean streamflow for the site. For comparison, the mean streamflow at FBR1 during the period 1970-1979 was $102 \mathrm{ft}^{3} / \mathrm{s}$.

The mean streamflow during the 18 month study period at sites FBR2 and FBR3 was 94 and $134 \mathrm{ft}^{3} / \mathrm{s}$, respectively (fig. 6B). Recorded flows at site FBR2 ranged from $8.2 \mathrm{ft}^{3} / \mathrm{s}$ (August 12, 2008) to $2,970 \mathrm{ft}^{3} / \mathrm{s}$ (January 7, 2009) during the study period. Recorded flows at site FBR3 ranged from $5.1 \mathrm{ft}^{3} / \mathrm{s}$ (July 22, 2008) to $3,700 \mathrm{ft}^{3} / \mathrm{s}$ (January 7, 2009) during the study period. The minimum flow recorded at FBR3, which is downstream from FBR2, is attributed to the combination of low flow as well as water withdrawals by CCSD.

A flow-duration curve is a cumulative frequency curve that shows the percentage of time specified discharges are equaled or exceeded during a given period (Searcy, 1959). Because flows during the study period were lower than normal, flow-duration curves developed for sites FBR2 and FBR3 cannot be considered representative of long-term, normal flow conditions. Thus, a flow-duration curve from site
FBR1 (period of record, 51 years) was used to determine the expected range of flows sampled.

Daily mean discharges for sites FBR2 and FBR3 were individually regressed against discharge for site FBR1 by using the Maintenance of Variance Extension (MOVE) fitting procedure to develop a correlation for each site (fig. 7). One of the key benefits in using the MOVE procedure is that the fitted line minimizes the errors for both the dependent and independent variables (Helsel and Hirsch, 2002). Flow-duration discharges for site FBR1 were input into these resulting equations to provide an estimate of discharge for selected magnitudes (table 2). These flow-duration curves and selected sampling discharges indicate that the samples were collected over the full range of expected flows (fig. 7).

\section{Suspended sediment}

Suspended-sediment concentrations in streams are affected by several factors, including soil characteristics, topography, land use, rainfall intensity, and streamflow. Samples for suspended-sediment analyses were collected approximately twice a week at sites FBR2 and FBR3 from mid-March 2008 through September 2009. The resulting 381 samples (188 at FBR2, and 193 at FBR3) represented suspended-sediment concentrations across almost the entire range of flows observed at both sites (fig. 8). Seven suspended-sediment samples were collected at site $\mathrm{KC} 1$ at flows ranging from 9.7 to $2,270 \mathrm{ft}^{3} / \mathrm{s}$. 
Table 2. Percentage of time discharge at study sites in Cleveland County, North Carolina, equaled or exceeded specified discharge in a given period.

[Site locations are shown in figure $1 . \mathrm{ft}^{3} / \mathrm{s}$, cubic foot per second]

\begin{tabular}{|c|c|c|c|}
\hline $\begin{array}{c}\text { Percent } \\
\text { exceedance }\end{array}$ & $\begin{array}{c}\text { FBR1 }^{\mathrm{a}} \\
\text { discharge, } \\
\text { in } \mathrm{ft}^{3} / \mathrm{s}\end{array}$ & $\begin{array}{c}\text { FBR2 }^{\mathrm{b}} \\
\text { discharge, } \\
\text { in } \mathrm{ft}^{3} / \mathrm{s}\end{array}$ & $\begin{array}{c}\text { FBR3 }^{\mathrm{b}} \\
\text { discharge, } \\
\text { in } \mathrm{ft}^{3} / \mathrm{s}\end{array}$ \\
\hline 95 & 21.9 & 41.8 & 53.0 \\
\hline 90 & 29.6 & 56.2 & 74.0 \\
\hline 85 & 35.1 & 66.5 & 89.4 \\
\hline 80 & 39.1 & 74.0 & 100.7 \\
\hline 75 & 42.8 & 80.9 & 111.3 \\
\hline 70 & 46.5 & 87.8 & 122.0 \\
\hline 65 & 50.2 & 94.7 & 132.8 \\
\hline 60 & 53.8 & 101.4 & 143.4 \\
\hline 55 & 58.2 & 109.6 & 156.4 \\
\hline 50 & 62.6 & 117.8 & 169.5 \\
\hline 45 & 67 & 125.9 & 182.8 \\
\hline 40 & 72.8 & 136.7 & 200.3 \\
\hline 35 & 78.6 & 147.4 & 218.1 \\
\hline 30 & 85.7 & 160.6 & 240.0 \\
\hline 25 & 94.7 & 177.2 & 268.0 \\
\hline 20 & 106 & 198.1 & 303.6 \\
\hline 15 & 121 & 225.7 & 351.4 \\
\hline 10 & 147.1 & 273.7 & 436.2 \\
\hline 5 & 214.5 & 397.2 & 662.1 \\
\hline Correlation & & 0.98 & 0.96 \\
\hline
\end{tabular}

${ }^{\text {a }}$ Computed on the basis of 40 years of record.

${ }^{\mathrm{b}}$ Based on daily value regression with FBR1 for the study period.

\section{Concentrations}

Because samples in this study were collected during diverse flow conditions, a wide range of suspended-sediment concentrations was observed at each of the study sites (fig. 9). Minimum concentrations measured at all sites were less than 10 milligrams per liter $(\mathrm{mg} / \mathrm{L})$ and as low as $1 \mathrm{mg} / \mathrm{L}$ at sites FBR2 and FBR3. Maximum suspended-sediment concentrations were $9,860 \mathrm{mg} / \mathrm{L}$ at site FBR2, 2,710 $\mathrm{mg} / \mathrm{L}$ at site FBR3, and 2,640 $\mathrm{mg} / \mathrm{L}$ at site $\mathrm{KC} 1$. Median concentrations were 10,11 , and $33 \mathrm{mg} / \mathrm{L}$, respectively. It should be noted that meaningful comparisons of concentrations among sites is difficult, because samples were collected at different times and at different flow conditions at each site. For instance, the lower number of samples collected at site $\mathrm{KC} 1$, most of which represented high-flow conditions, resulted in relatively high median concentrations.

During 1977-1983, a total of 29 suspended-sediment samples were collected at site FBR1. Concentrations ranged from 1 to $1,290 \mathrm{mg} / \mathrm{L}$, with a median value of $7 \mathrm{mg} / \mathrm{L}$ for streamflow samples ranging from 34 to $1,760 \mathrm{ft}^{3} / \mathrm{s}$. Although the maximum suspended-sediment concentration from samples collected at site FBR1 is considerably lower than sites FBR2 and FBR3, the median concentrations are similar. The difference in maximum suspended-sediment concentrations can be attributed to differing flow conditions during the sampling events.

\section{Particle-Size Distribution}

Suspended sediment consists of particles small enough to be transported in suspension - primarily sands, silts, and clays. Selected suspended-sediment samples (based on visual inspection) from the First Broad River study sites were analyzed to determine the percentage of particles finer than $0.0625 \mathrm{~mm}$, which corresponds to the breakpoint between sands $(0.0625$ to $2.0 \mathrm{~mm}$ in diameter) and the finer particulates known as silts and clays. Fifty-three of 188 suspended-sediment samples were analyzed at site FBR2, and 59 of 193 suspendedsediment samples were analyzed at site FBR3, for the range of flows observed during the study period. The range in percentage of fine-grained particles was 6 to 95 percent at site FBR2 and 30 to 99 percent at site FBR3 (fig. 10). The percentage of fine-grained particles varied widely as related to flow, most notably during high-flow conditions. In general, high percentages of fine-grained particles were found in samples collected at low flows, and low percentages of fine-grained particles were found in samples collected at high flows. The median percentage of fine-grained particles was 69 percent at site FBR2, and 66 percent at site FBR3 (fig. 10), which suggests that the suspended-sediment particles transported at the two sites tend to have similar size distributions and silts and clays make up the majority of sediment particles in flux at these locations.

The percentage of particles finer than $0.0625 \mathrm{~mm}$ at site $\mathrm{KC} 1$ ranged from 45 to 96 , with a median of 78 percent (fig. 10). Because only six samples were analyzed at site $\mathrm{KC} 1$ for the sand-fine breakpoint, site-to-site comparisons are limited; however, the results indicate that sediment flux at this location is also dominated by fine-grain particles.

\section{Loads}

Instantaneous suspended-sediment loads, in tons per day, were calculated from instantaneous streamflow and instantaneous suspended-sediment concentrations at sites FBR2, FBR3, and KC1. Suspended-sediment loads were estimated for sites FBR2 and FBR3 using LOADEST (Runkel and others, 2004) - a menu-driven system for estimating constituent loads in streams and river. LOADEST uses a regression model to estimate loads for a user-specified interval and allows the user to choose among several predefined models, or the software is allowed to choose the best model based on the Akaike Information Criterion (Akaike, 1981). For this study, the software was allowed to choose the best model (model 9) using the Adjusted Maximum Likelihood Estimation (AMLE) 


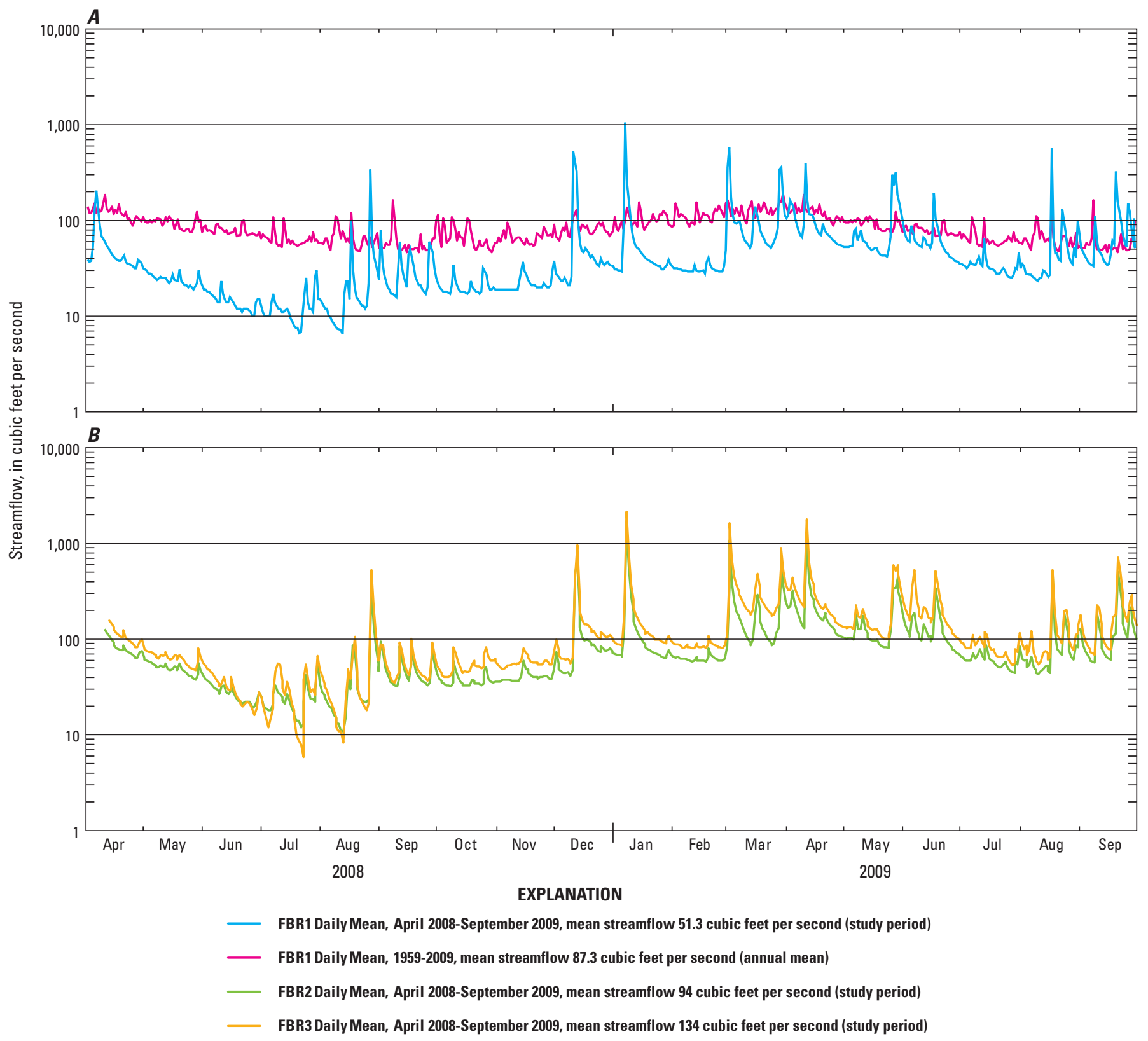

Figure 6. (A) daily mean streamflow for April 2008-September 2009 and long-term daily mean streamflow, 1959-2008, at First Broad River near Casar (site FBR1) and (B) daily mean streamflow for April 2008-September 2009 at First Broad River at Secondary Road 1512 near Lawndale (site FBR2) and First Broad River at Lawndale (site FBR3), Cleveland County, North Carolina.

method. The regression equation (Runkel and others, 2004) for computing suspended-sediment loads in tons per day is

$$
\begin{aligned}
\ln (\mathrm{L})= & a_{0}+a_{1} \ln Q+a_{2} \ln Q^{2}+a_{3} \sin (2 \pi \text { dtime })+a_{4} \\
& \cos (2 \pi \text { dtime })+\text { a } 5 \text { dtime }+a_{6} \text { dtime } e^{2}
\end{aligned}
$$

where:

$\mathrm{L} \quad$ is constituent load, in tons per day;

$a_{0}-a_{6} \quad$ are model-determined regression coefficients;

ln is natural log;

$Q \quad$ is discharge; and

dtime is decimal time.
Statistical data from the selected model was evaluated to check that the model residuals were normally distributed (probability plot correlation coefficient, Vogel, 1986; and Turnbull-Weiss likelihood ratio, Turnbull and Weiss, 1978). Although the Turnbull-Weiss likelihood ratio (p-value) was less than 0.05 for site FBR3 (0.001), which suggests that the residuals were not normally distributed, the AMLE method was used. The model was re-run after removing two potential outliers, resulting in a p-value of 0.10 and a change of total load estimate of only 3 percent. Loads were not computed at site $\mathrm{KC1}$, because this computation was not an objective of this study. 


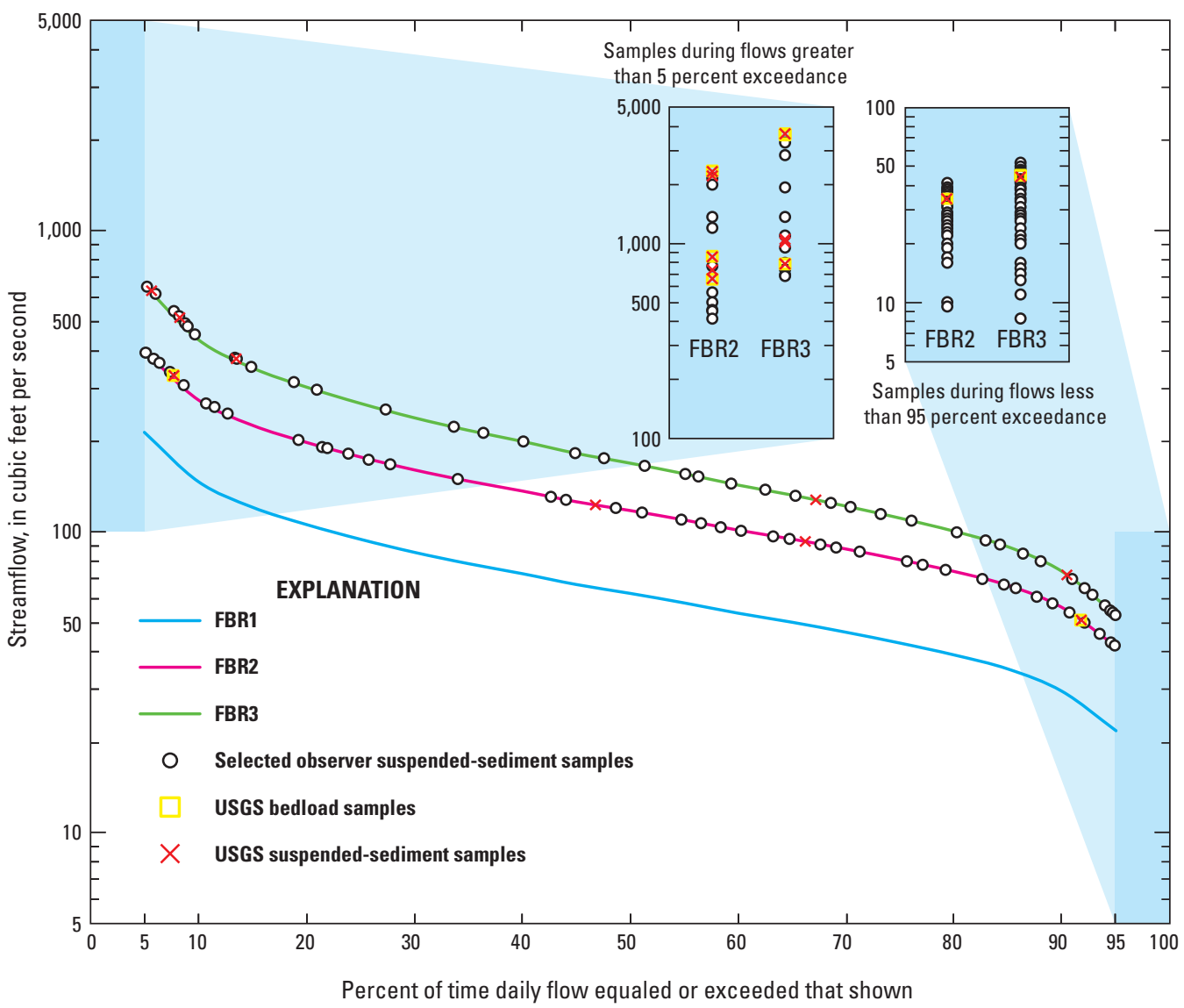

Figure 7. Flow duration curves for sites FBR1, FBR2, and FBR3, and corresponding sample streamflow at sites FBR2 and FBR3, Cleveland County, North Carolina.

The relation between suspended-sediment concentrations and discharge for sites FBR2 and FBR3 is shown in figure 11. Estimation files containing daily discharge data, in cubic feet per second, were used by the software to estimate daily, monthly, and seasonal (water year) loads for the study period. Measured instantaneous suspended-sediment loads for sites FBR2 and FBR3 were plotted against the estimated loads for the same day to visually assess the fit of the selected model (fig. 12). Points that plot above the 1:1 line indicate that the estimated value is smaller than the measured value, and points that plot below the line indicate that the estimated value is larger than the measured value. Ideally, all points would plot on the line. At site FBR2, points plot close to and are evenly distributed across the 1:1 line, suggesting that the model performed reasonably well (fig. 12A). At site FBR3, more points plot below the line (mostly for small loads), suggesting that the model may have slightly overestimated loads at this site (fig. 12B). Consequently, it appears that the model performed reasonably well at moderate to large loads for site FBR3.

Estimated monthly suspended-sediment loads and mean daily streamflow for April 2008-September 2009 for sites FBR2 and FBR3 are shown in figure 13. As expected, the estimated monthly loads at site FBR3 are generally higher than at site FBR2. The total suspended-sediment loads during the 2009 water year were 19,000 tons at site FBR2 and 37,000 tons at site FBR3 (fig. 13). Total daily loads from seven high-flow (storm) events accounted for 26.4 percent and 17.5 percent of the total 2009 water year load at sites FBR2 and FBR3, respectively (table 3). These seven events included a 1-day (January 7, 2009) daily load that accounted for 9.6 percent (FBR2) and 5.4 percent (FBR3) of the total 2009 water year load, which suggests that the bulk of the total suspended-sediment load is transported during high-flow events.

The suspended-sediment yield during the 2009 water year was 147 tons per square mile (ton/mi ${ }^{2}$ ) at site FBR2 and $195 \mathrm{ton} / \mathrm{mi}^{2}$ at site FBR3 (table 1). Estimated mean annual suspended-sediment yield at site FBR1 during 1970-1979 was $250 \mathrm{ton} / \mathrm{mi}^{2}$. Low-flow conditions during the study period and mild stream gradients at sites FBR2 and FBR3 are two factors that could contribute to the decreased yields at these sites.

\section{Bedload}

Samples for bedload analyses were collected on five to seven separate dates at each of the three study sites. Samples collected on August 26, 2008, and August 4, 2009, represent base-flow conditions (less than 90 percent exceedance), and the remaining bedload samples were collected during 

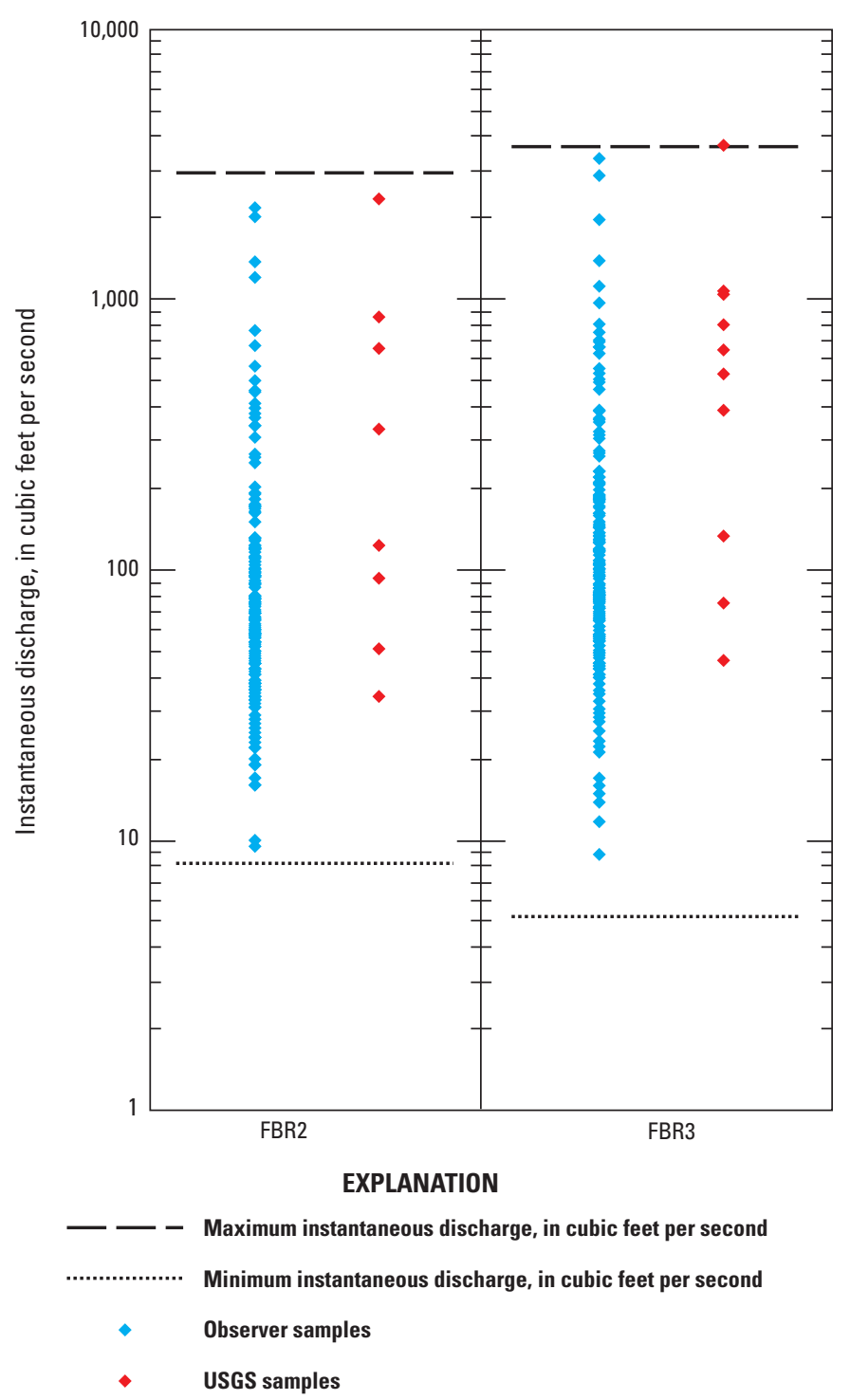

Figure 8. Range of streamflow measured during the study period and the discharge associated with suspended-sediment samples collected between March 2008 and September 2009 at sites FBR2 and FBR3, Cleveland County, North Carolina.

EXPLANATION

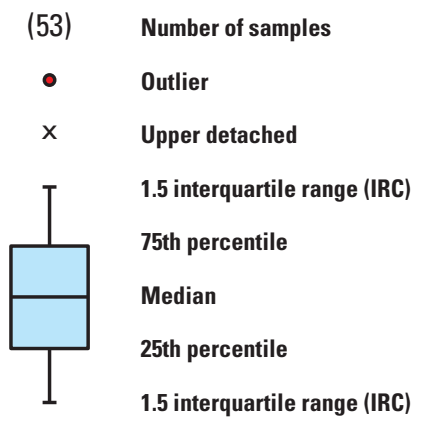

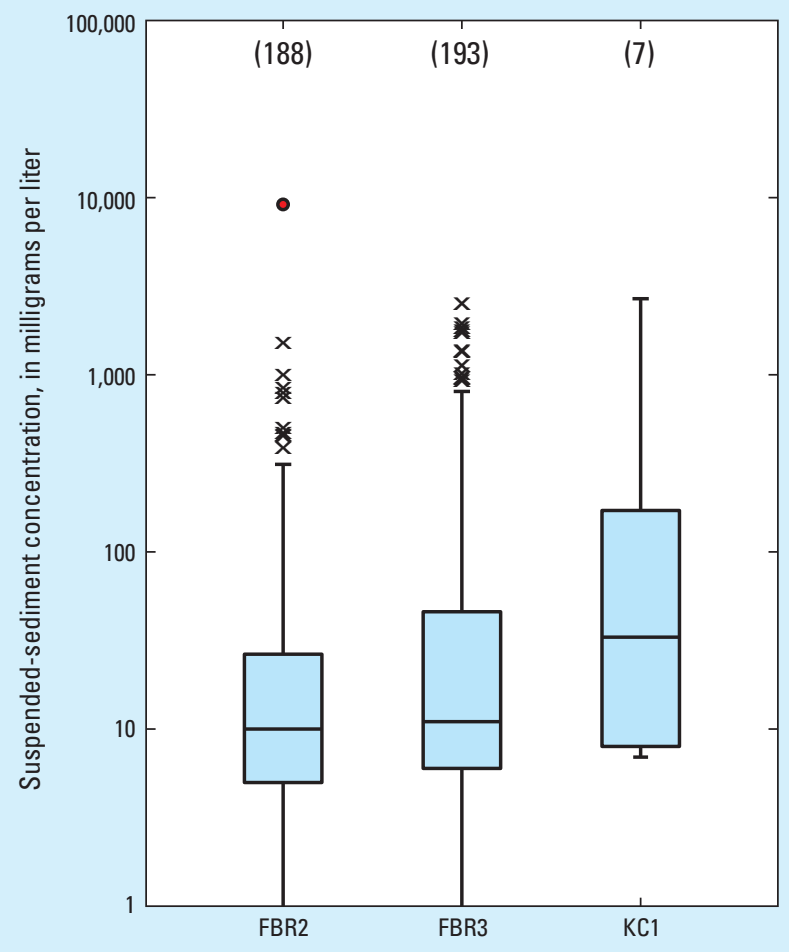

Figure 9. Distribution of suspended-sediment concentrations from samples collected between March 2008 and September 2009 at FBR2, FBR3, and KC1, Cleveland County, North Carolina.

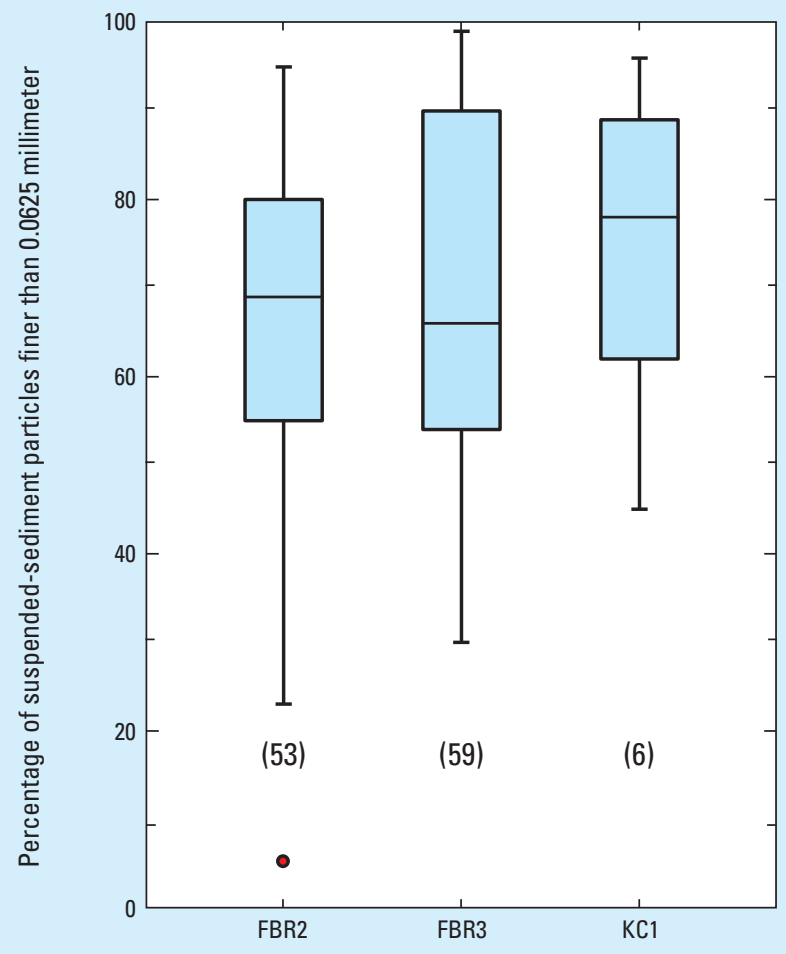

Figure 10. Distribution of percentages of suspendedsediment particles finer than 0.0625 millimeters from samples collected between March 2008 and September 2009 at FBR2, FBR3, and KC1, Cleveland County, North Carolina. 


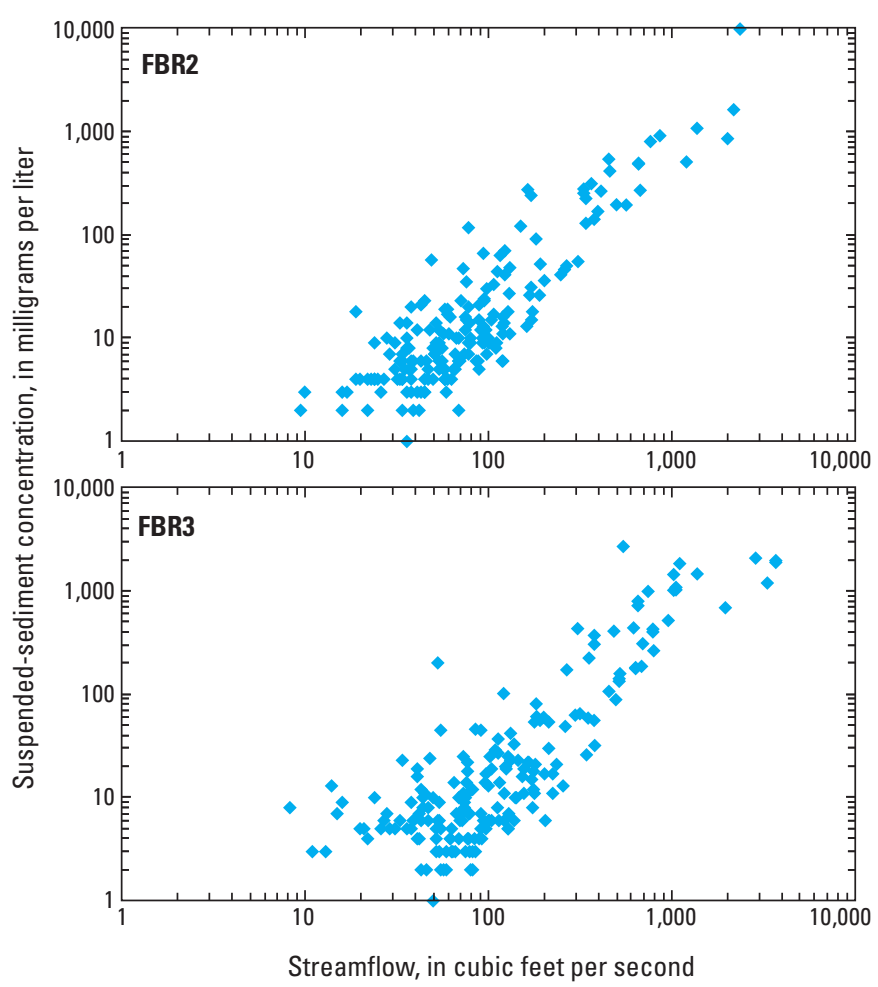

Figure 11. Relation between instantaneous suspended-sediment concentration and streamflow at sites FBR2 and FBR3, Cleveland County, North Carolina.

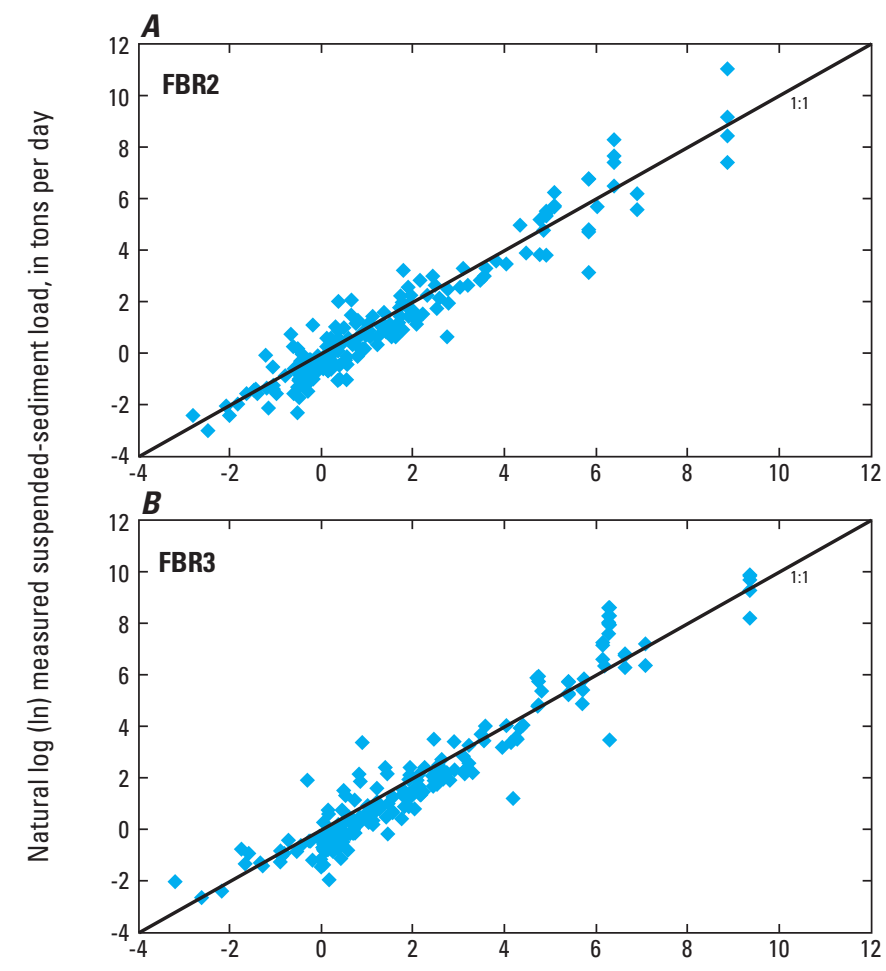

Natural log (In) estimated suspended-sediment load, in tons per day

Figure 12. Relation between estimated and measured suspended-sediment loads at sites FBR2 $(A)$ and FBR3 $(B)$, Cleveland County, North Carolina. high-flow events (greater than 5 percent exceedance (table 4; fig. 7). Because most bedload samples were collected during periods of extreme flow conditions, only the relative contribution of bedload samples to total sediment load can be assessed.

\section{Particle-Size Distribution}

Each bedload sample was analyzed for particle-size distribution ranging from percentage of particles that were less than $0.0625 \mathrm{~mm}$ to the percentage less than $16 \mathrm{~mm}$. The median percentage of bedload finer than $1 \mathrm{~mm}$ was 61 percent at site FBR2 and 65 percent at site FBR3. As with suspendedsediment particles, the size of the bedload particles being transported at the two sites is similar in size.

The median percentage of bedload finer than $1 \mathrm{~mm}$ was 90 percent at site $\mathrm{KC1}$. Based on these data, the size of the bedload particles being transported at site $\mathrm{KC} 1$ is significantly smaller than the bed material particles being transported at sites FBR2 and FBR3.

\section{Loads}

The average streamflow during the sampling period, stream width, number of subsections, length of time the sampler was on the streambed at each subsection, and total sampling time were recorded for the three study sites (table 4). This information, along with the analyzed weight of the composited material, was used to compute bedload for each sampling event. The equation (Edwards and Glysson, 1999, p. 80) for the computation of bedload, in tons per day, is:

where

$$
Q_{B}=K \frac{W_{T}}{t_{T}} M_{T},
$$

$Q_{B} \quad$ is bedload discharge, as measured by bed load sampler, in tons per day;

$W_{T} \quad$ is total width of sampled cross section, in feet; $t_{T} \quad$ is total time the sampler was on the bed, in seconds, computed by multiplying the individual sample time by the number of subsamples;

$M_{T} \quad$ is total mass of sample collected from all verticals in the cross section, in grams; and

$K \quad$ is a conversion factor used to convert grams per second per foot into tons per day per foot. The conversion factor for the BL-84 samplers with a 3 -inch opening is 0.381 (Edwards and Glysson, 1999).

Instantaneous bedload during base-flow conditions ranged from 0.97 to 9.9 tons per day (tons/d) at site FBR2, 0.05 to 2.1 tons/d at site FBR3, and 0.03 to 2.4 tons/d at site $\mathrm{KC} 1$ (table 5). At elevated flows, the instantaneous bedload ranged from 12.8 to 258.2 tons/d at site FBR2, 4.2 to 150.1 tons/d at site FBR3, and 2.4 to 21.0 tons/d at site KC1. 

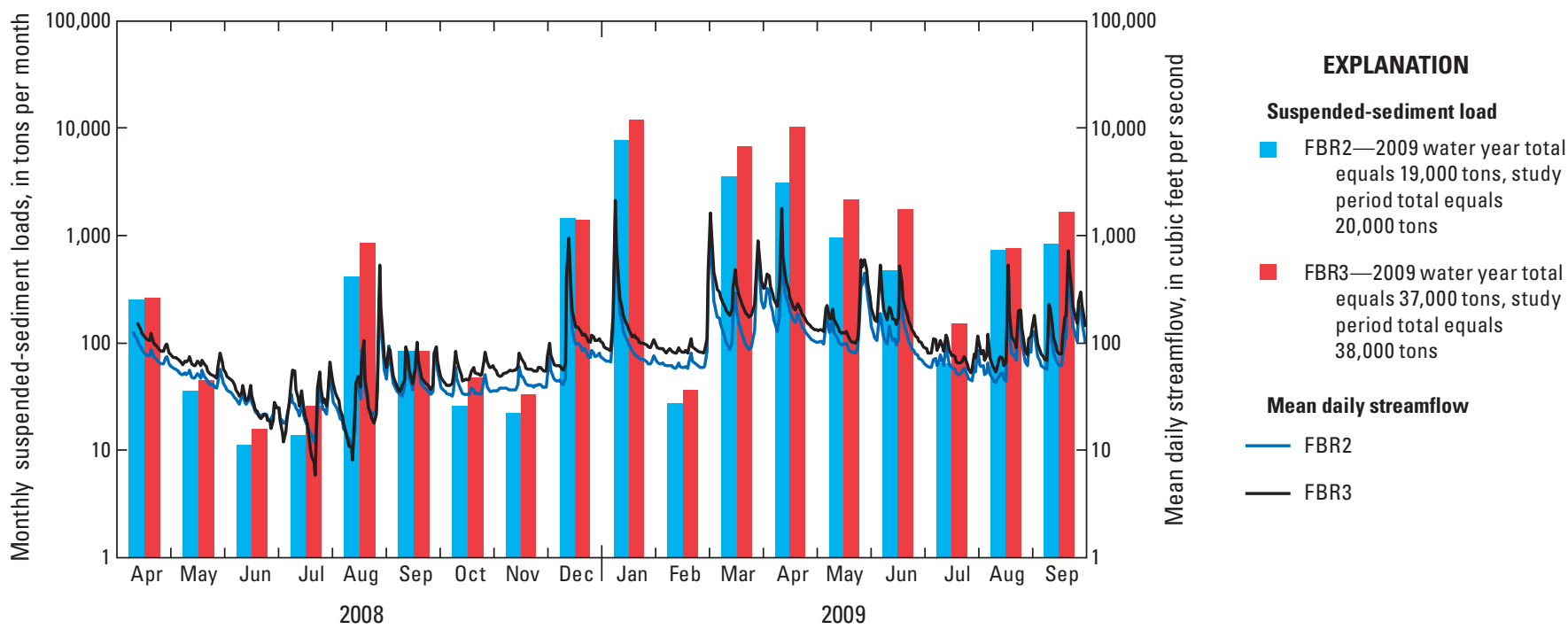

Figure 13. Estimated monthly suspended-sediment load and mean daily streamflow from April 2008 to September 2009 at FBR2 and FBR3, Cleveland County, North Carolina.

The highest instantaneous loads were recorded during the January 7, 2009, sampling event at all study sites. In general, the bedload concentrations tended to be higher at site FBR2 than site FBR3. This difference can be attributed to the channel morphology (narrower channel) and higher velocities measured at site FBR2. Site KC1 had the lowest bedload concentrations, which is consistent with the finding that a high percentage of the suspended sediment was fine grained.

The range in percentages of total load that is bedload at elevated flow conditions (when the bulk of sediment is transported) was 0.4 to 17 percent at site FBR2, 0.1 to 6.1 percent at site FBR3, and 0.1 to 28 percent at site $\mathrm{KC} 1$. During the extreme runoff event on January 7, 2009, bedload was 0.4 percent of the total load at site FBR2, 0.8 percent at site FBR3 and 0.1 percent at site $\mathrm{KC} 1$, which indicates that the percentage of the total load that is bedload during extreme runoff conditions is not significant at the three sites. The percentages of the total load that is bedload during low-flow conditions ranged from 0.1 to 90.8 , which indicates that the bedload is indeed variable both spatially and temporally.

\section{Summary}

The U.S. Geological Survey began a study of sediment transport in March 2008 in cooperation with the Cleveland County Sanitary District in order to characterize suspendedsediment and bedload transport in the First Broad River Basin, both upstream and downstream from a proposed dam location, north of the town of Lawndale in Cleveland County, North Carolina. This report includes data collected between March 2008 and September 2009.

Table 3. Total daily suspended-sediment loads at study sites in Cleveland County, North Carolina, for seven high-flow events during the 2009 water year.

[Site locations are shown in figure 1. Values shown in italics indicate a 1-day daily load. WY, water year: October 1-September 30 and identified by the year in which the period ends]

\begin{tabular}{|c|c|c|c|c|c|c|}
\hline \multirow[b]{2}{*}{ Event date } & \multicolumn{3}{|c|}{ FBR2 } & \multicolumn{3}{|c|}{ FBR3 } \\
\hline & Daily loads & $\begin{array}{c}\text { Percent of } \\
\text { monthly total }\end{array}$ & $\begin{array}{c}\text { Percent of } \\
\text { WY } 2009 \text { total }\end{array}$ & Daily loads & $\begin{array}{c}\text { Percent of } \\
\text { monthly total }\end{array}$ & $\begin{array}{c}\text { Percent of } \\
\text { WY } 2009 \text { tota }\end{array}$ \\
\hline 01-07-2009 & 1,800 & 23.6 & 9.6 & 2,000 & 16.5 & 5.4 \\
\hline 03-02-2009 & 740 & 21.3 & 4.0 & 1000 & 14.6 & 2.7 \\
\hline 08-17-2009 & 420 & 58.0 & 2.2 & 360 & 47.7 & 1.0 \\
\hline 09-20-2009 & 320 & 38.3 & 1.7 & 440 & 27.1 & 1.2 \\
\hline Event totals & 4,900 & & 26.4 & 6,500 & & 17.5 \\
\hline
\end{tabular}


Table 4. Bedload samples collected at sites FBR1, FBR2, and KC1, in Cleveland County, North Carolina, March 2008-September 2009.

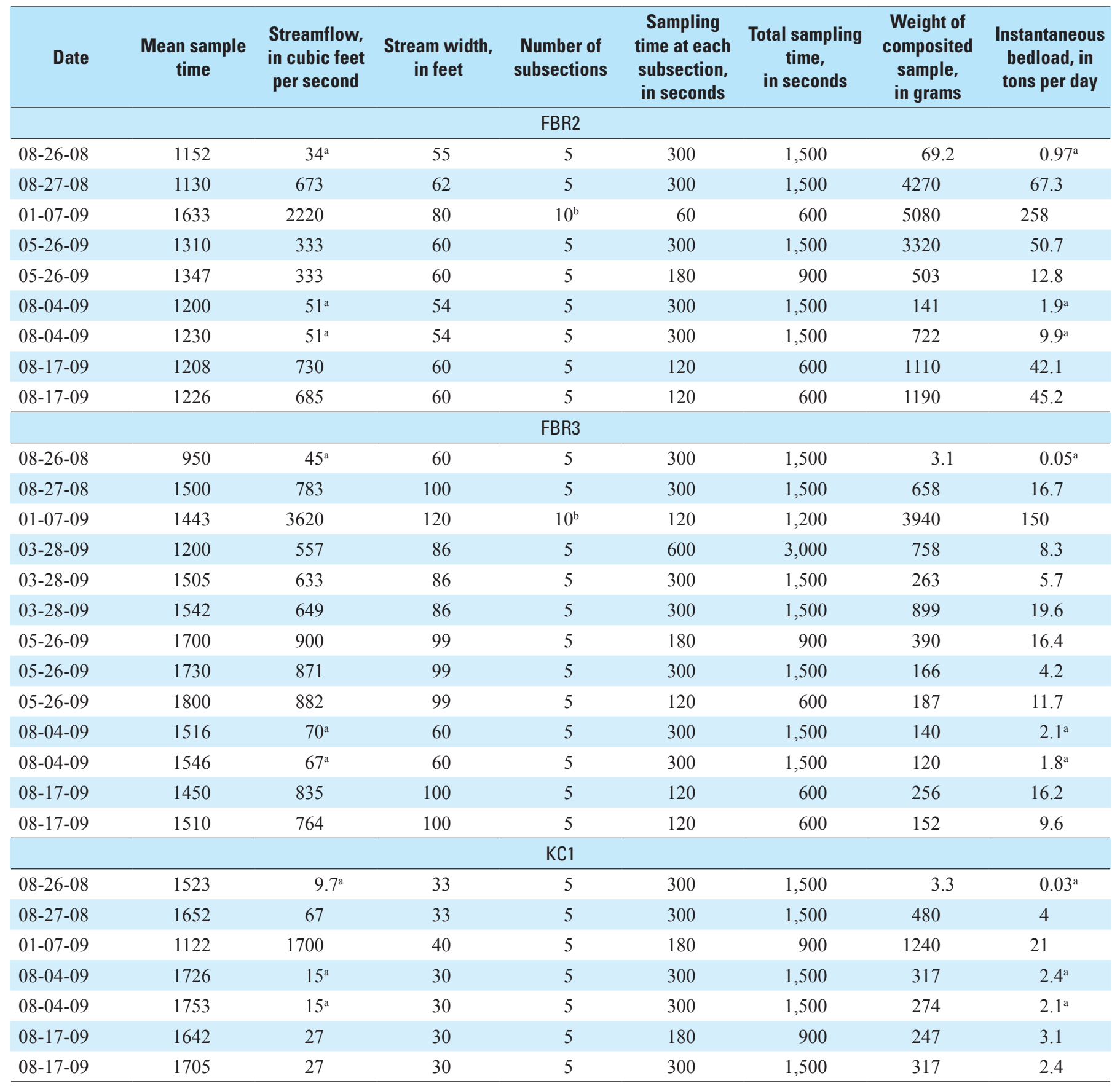

${ }^{a}$ Base-flow conditions.

${ }^{\mathrm{b}}$ Two transects composited.

Continuous streamflow and 381 suspended-sediment samples were collected at two study sites on the First Broad River to define the relation between suspended-sediment concentration and streamflow. Twenty-two bedload samples were collected at the two study sites to determine the contribution of bedload to the total sediment load. Seven suspended-sediment and seven bedload samples also were collected at Knob Creek to characterize the suspended-sediment and bedload characteristics of this tributary to the First Broad River. Total loads were not determined at this site.

Although total precipitation for the study period was slightly above normal, the beginning of the study period (through April 2009) was affected by considerable drought, which resulted in below normal streamflow for most of the study period. The long-term annual mean streamflow for the period 1959 through 2009 was 
Table 5. Instantaneous suspended-sediment load, bedload, and total load for samples collected at sites FBR2, FBR3, and KC1, Cleveland County, North Carolina, March 2008-September 2009.

[ft $/ \mathrm{s}$, cubic foot per second; ton/d, tons per day; SS, suspended-sediment load; BL, bedload]

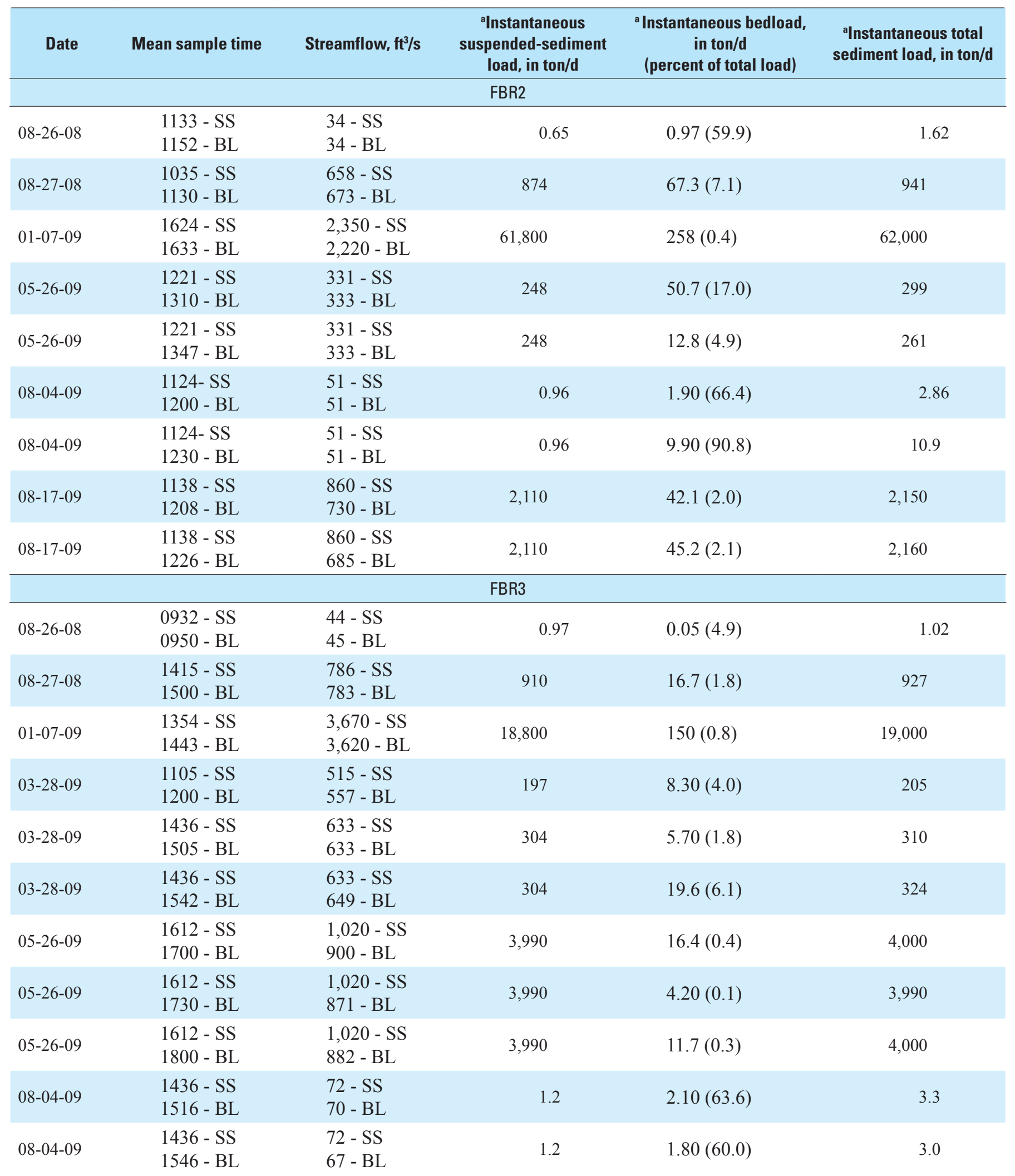


Table 5. Instantaneous suspended-sediment load, bedload, and total load for samples collected at sites FBR2, FBR3, and KC1, Cleveland County, North Carolina, March 2008-September 2009.-Continued

[ft³/s, cubic foot per second; ton/d, tons per day; SS, suspended-sediment load; BL, bedload]

\begin{tabular}{|c|c|c|c|c|c|}
\hline Date & Mean sample time & Streamflow, $\mathrm{ft}^{3} / \mathrm{s}$ & $\begin{array}{c}\text { alnstantaneous } \\
\text { suspended-sediment } \\
\text { load, in ton/d }\end{array}$ & $\begin{array}{l}\text { a Instantaneous bedload, } \\
\text { in ton/d } \\
\text { (percent of total load) }\end{array}$ & $\begin{array}{l}\text { alnstantaneous total } \\
\text { sediment load, in ton/d }\end{array}$ \\
\hline 08-17-09 & $\begin{array}{l}1331-\mathrm{SS} \\
1450-\mathrm{BL}\end{array}$ & $\begin{array}{l}1,050-\mathrm{SS} \\
835-\mathrm{BL}\end{array}$ & 2,920 & $16.2(0.6)$ & 2,940 \\
\hline 08-17-09 & $\begin{array}{l}1331-\mathrm{SS} \\
1510-\mathrm{BL}\end{array}$ & $\begin{array}{l}1,050-\mathrm{SS} \\
764-\mathrm{BL}\end{array}$ & 2,920 & $9.6(0.3)$ & 2,930 \\
\hline 08-26-08 & $\begin{array}{l}1501-\mathrm{SS} \\
1523-\mathrm{BL}\end{array}$ & $\begin{array}{l}9.7-\mathrm{SS} \\
9.7-\mathrm{BL}\end{array}$ & 0.68 & $0.03(4.2)$ & 0.71 \\
\hline $08-27-08$ & $\begin{array}{l}1624-\mathrm{SS} \\
1652-\mathrm{BL}\end{array}$ & $\begin{array}{l}67-\mathrm{SS} \\
67-\mathrm{BL}\end{array}$ & 31 & $4.00(11.4)$ & 35 \\
\hline 01-07-09 & $\begin{array}{l}1041-\mathrm{SS} \\
1122-\mathrm{BL}\end{array}$ & $\begin{array}{l}2,270-\mathrm{SS} \\
1,700-\mathrm{BL}\end{array}$ & 16,200 & $21.0(0.1)$ & 16,200 \\
\hline 08-04-09 & $\begin{array}{l}1700-\mathrm{SS} \\
1753-\mathrm{BL}\end{array}$ & $\begin{array}{l}15-\mathrm{SS} \\
15-\mathrm{BL}\end{array}$ & 0.31 & $2.10(87.1)$ & 2.41 \\
\hline 08-17-09 & $\begin{array}{l}1613-\mathrm{SS} \\
1642-\mathrm{BL}\end{array}$ & $\begin{array}{l}27-\mathrm{SS} \\
27-\mathrm{BL}\end{array}$ & 7.9 & $3.10(28.2)$ & 11.0 \\
\hline 08-17-09 & $\begin{array}{l}1613-\mathrm{SS} \\
1705-\mathrm{BL}\end{array}$ & $\begin{array}{l}27-\mathrm{SS} \\
27-\mathrm{BL}\end{array}$ & 7.9 & $2.40(23.3)$ & 10.3 \\
\hline
\end{tabular}

${ }^{\text {a }}$ Instantaneous loads are extrapolated assuming this constant rate and expressed in units of tons per day. These instantaneous load values, therefore, may exceed daily loads computed on the basis of varying flow conditions.

87.3 cubic feet per second $\left(\mathrm{ft}^{3} / \mathrm{s}\right)$ at site FBR 1 . The mean streamflow at site FBR1 during the study period was $51.3 \mathrm{ft}^{3} / \mathrm{s}$, which was approximately 60 percent of the long-term annual mean streamflow for the site. The mean streamflow during the study period at sites FBR2 and FBR3 was $94 \mathrm{ft}^{3} / \mathrm{s}$ and $134 \mathrm{ft}^{3} / \mathrm{s}$, respectively.

Maximum suspended-sediment concentrations from samples collected at the study sites were 9,860 milligrams per liter (mg/l) at site FBR2, 2,710 mg/l at site FBR3 and $2,640 \mathrm{mg} / 1$ at site $\mathrm{KC} 1$. The maximum suspended-sediment concentration from samples collected at FBR1 during the period 1970 through 1979 was $1,290 \mathrm{mg} / \mathrm{l}$. The percentage of fine-grained particles (less than 0.0625 millimeters) as related to flow was widely variable, most notably during high-flow conditions. In general, higher percentages of fine-grained particles were found in samples collected at lower flows. The median percentage of fine-grained particles was 69 percent at site FBR2 and 66 percent at site FBR3, which suggests that the suspended-sediment particles transported at the two sites tend to have similar size distributions and silts and clays make up the majority of sediment particles in flux at these locations.
The total suspended-sediment loads during the 2009 water year were 19,000 tons at site FBR2 and 37,000 tons at site FBR3. High-flow events accounted for a large percentage of the total load, which suggests that the bulk of the total suspended-sediment load is transported during these events. The suspended-sediment yield during the 2009 water year was 147 tons per square mile (ton $\left./ \mathrm{mi}^{2}\right)$ at site FBR2 and $195 \mathrm{ton} / \mathrm{mi}^{2}$ at site FBR3. The estimated mean annual suspended-sediment yield for the period 1970 through 1979 was $250 \mathrm{ton} / \mathrm{mi}^{2}$. Low-flow conditions during the study period and milder stream gradients at FBR2 and FBR3 are two factors that could contribute to the decreased yields at these sites.

During high-flow events, the percentage of the total load that the bedload contributed ranged from approximately 0.1 to 0.8 percent of the total load at the three study sites. These percentages indicate that during high-flow conditions the percentage of the total load that is bedload is not significant at the three sites. The percentages of the total load that is bedload during base-flow conditions ranged from 0.1 to 90.8 , which indicates that the bedload is indeed variable, both spatially and temporally. 


\section{References}

Akaike, Hirotugu, 1981, Likelihood of a model and information criterion: Journal of Econometrics, v. 16, p. 3-14.

Davis, B.E., 2005, A guide to the proper selection and use of federally approved sediment and water-quality samplers: U.S. Geological Survey Open-File Report 2005-1087, 20 p.

Edwards, T.K., and Glysson, G.D., 1999, Field methods for measurement of fluvial sediment: U.S. Geological Survey Techniques of Water-Resources Investigations, book 3, chap. C2, 89 p.

Guy, H.P., 1969, Laboratory theory and methods for sediment analysis: U.S. Geological Survey Techniques of WaterResources Investigations, book 5, chap. C1, 58 p.

Helsel, D.R., and Hirsch, R.M., 2002, Statistical methods in Water Resources: U.S. Geological Survey Techniques of Water-Resources Investigations, book 4, chap. A3, 522 p.

Johnson, G.P., 1997, Instruction manual for U.S. Geological Survey sediment observers: U.S. Geological Survey OpenFile Report 96-431, 37 p.

Mueller, D.S., and Wagner, C.R., 2009, Measuring discharge with acoustic Doppler current profilers from a moving boat: U.S. Geological Survey Techniques and Methods 3A-22, 72 p. (Also available at $h t t p: / / p u b s . u s g s . g o v / t m / 3 a 22 /$.)

National Oceanic and Atmospheric Administration, National Climatic Data Center, National Environmental Satellite, Data, and Information Service, Historical Palmer Drought Indices, accessed April 27, 2011, at http://www.ncdc.noaa. gov/temp-and-precip/drought/historical-palmers.php.

Natural Resources Conservation Service, 2006, Soil survey of Cleveland County, North Carolina: U.S. Department of Agriculture, accessed April 27, 2011, at http://soildatamart. nrcs.usda.gov/Manuscripts/NC045/0/Cleveland.pdf.

Rantz, S.E., and others, 1982, Measurement and computation of streamflow: U.S. Geological Survey Water-Supply Paper 2175 , v. 1 and 2, 631 p.

Runkel, R.L., Crawford, C.G., and Cohn, T.A., 2004, Load Estimator (Loadest): A FORTRAN program for estimating constituent loads in streams and rivers: U.S. Geological Survey Techniques and Methods, book 4, chap. A5, 69 p.

Searcy, J.K., 1959, Flow-duration curves, Manual of hydrology, Part 2, Low-flow techniques: U.S. Geological Survey Water-Supply Paper 1542-A, 33 p., accessed April 27, 2011, at http://pubs.er.usgs.gov/usgspubs/wsp/wsp1542A.
Shreve, E.A., and Downs, A.C., 2005, Quality-assurance plan for the analysis of fluvial sediment by the U.S. Geological Survey Kentucky Water Science Center Sediment Laboratory: U.S. Geological Survey Open-File Report 2005-1230, $28 \mathrm{p}$.

Simmons, C.E., 1993, Sediment characteristics of North Carolina streams, 1970-79: U.S. Geological Water-Supply Paper 2364, 84 p.

Simpson, M.R., 2001, Discharge measurements using a broadband acoustic Doppler current profiler: U.S. Geological Survey Open-File Report 01-1, 123 p.

State Climate Office of North Carolina, CRONOS database, Casar (311538), accessed April 27, 2011, at http://www.nc-climate.ncsu.edu/cronos/?station $=311538$.

Turnbull, B.W., and Weiss, L., 1978, A likelihood ratio statistic for testing goodness of fit with randomly censored data: Biometrics, v. 34, no. 3, p. 367-375.

U.S. Geological Survey, 2009, Water-resources data for the United States, Water Year 2008: U.S. Geological Survey Water-Data Report WDR-US-2008, accessed April 27, 2011, at http://wdr.water.usgs.gov/.

U.S. Geological Survey, 2010, Water-resources data for the United States, Water Year 2009: U.S. Geological Survey Water-Data Report WDR-US-2009, accessed April 27, 2011, at http://wdr.water.usgs.gov/.

U.S. Geological Survey, 2011, Water-resources data for the United States, Water Year 2010: U.S. Geological Survey Water-Data Report WDR-US-2010, accessed April 27, 2011, at http://wdr.water.usgs.gov/.

Vogel, R.M., 1986, The probability plot correlation coefficient test for the normal, lognormal, and Gumbel distributional hypotheses: Water Resources Research, v. 22, no. 4, p. 587-590. 


\section{Glossary}

annual mean streamflow The arithmetic mean of the daily-mean streamflows for the year noted or for the designated period. For example, the annual-mean streamflow for 1959-2009 is the arithmetic mean of all daily-mean streamflow for that period.

bedload sediment Particles in transit from the bed to an elevation equal to the top of the bed-load sample nozzle (usually within 0.25 feet of the streambed).

daily mean streamflow The mean streamflow for any one day. For example, the daily-mean streamflow for October 12, 2008.

particle-size distribution In this report, sediment grain size is expressed using the Wentworth scale. Grain-size classes used in this report include:

Gravel: grains from $2 \mathrm{~mm}$ to $64 \mathrm{~mm}$ in diameter

Sand: grains from $0.0625 \mathrm{~mm}$ to $2 \mathrm{~mm}$ in diameter

Silt and clay: smaller than $0.0625 \mathrm{~mm}$ in diameter

suspended sediment Very fine soil particles that remain in suspension in water for a considerable period of time without contact with the bottom. Such material remains in suspension because of the upward components of turbulence and currents and (or) by suspension. 
Prepared by:

USGS Science Publishing Network

Raleigh Publishing Service Center

3916 Sunset Ridge Road

Raleigh, NC 27607

USGS Publishing Service Center staff:

Kay Naugle, Editor

James A. Tomberlin, Illustrator and layout

For additional information regarding this publication, contact:

Director

USGS North Carolina Water Science Center

3916 Sunset Ridge Road

Raleigh, NC 27607

email: dc_nc@usgs.gov

Or visit USGS North Carolina Water Science Center at:

http://nc.water.usgs.gov/ 

